Körösi Zsuzsa

Párizs-Budapest

\title{
Petíció az abortusz-szabadság megőrzéséért 1973 (2. rész)
}

Jelen tanulmány tárgya a nagyrészt feledésbe merült, a nők abortusz-jogának megszigorítása ellen szervezett 1973-as petíció-akció. A szerző, aki maga is aktív résztvevő, rekonstruálja a petíció történetét Magyar Nemzeti Levéltár (MNL), az Állambiztonági Szolgálatok Történeti Levéltár (ÁBTL) kutatók számára rendelkezésre álló dokumentumai, a Blinken OSA Archívumban található dokumentumok, valamint a petíció-akció 19 résztvevőjével készített interjúk felhasználásával. Az interjúk legépelt formában a Blinken OSA Archívumban olvashatók (HU OSA 432, Körösi Zsuzsa interjúgyújteménye). Az alábbi cikk a második rész. Az első rész a Magyar Népi Demokrácia népességpolitikáját vázolta fel, annak konzervatív fejlődését 1956 és 1973 között. Ez az elnyomó politikai kontextus vezetett a nők abortusz-jogának megszigorításához, ami a petíció szervezését váltotta ki. Ez a II. rész három fő kérdésre ad választ az intejúalanyok véleményének tükrében: mit jelentett a „szabad” abortusz a nők és férfiak számára 1956 és 1973 között; mi tekinthető a petíció ideológiai gyökereinek; illetve a szervezésében résztvevők motivációi és a hatalom szankció, melyekkel a résztvevőknek számolnia kellett.

\section{6-1973 a terhességmegszakítás törvényes lehetőségének időszaka: Személyes emlékek}

A tanulmány második részében azokat a tényezôket, érveket fogom csoportosítani, amelyek a tizenkilenc petíció-akcióban résztvevő beszélgetôpartnerem számára indokolttá, fontossá tette a petíció aláirását, illetve az aláirást követő retorziókat felidéző visszaemlékezéseikből, a Magyar Nemzetti Levéltárban és az Állambiztonsági Szolgálatok Történeti Levéltárban található archív anyagok alapján igyekszem az 1973-as petíció jelentőségét felvázolni. A korabeli anyagok és az egykori résztvevők visszaemlékezései alapján azt állítom, hogy a Kádár-korszak magyar demokratikus ellenzékének megszületését nem az 1978-as csehszlovák Charta 
77-hez ${ }^{1}$ csatlakozó aláírásgyújtéshez kellene datálni, hanem az 1973-as úgynevezett abortusz-petícióhoz.

Az interjúk közlóinek nevét nem anonimizáltam, mert három interjúalany kivételével valamennyi írásban beleegyezett, hogy a nevükkel idézzek a velük készült interjúkból. A három fiktív néven szereplő személy Szebeni Jenő, Damásdi Diána és Karakán Melinda. Az interjúk elkészítéséhez több kérdéskört határoztam meg, az elemzés ezek mentén halad. A „Miért írtad alá?" kérdéstömbben tettem fel azt a kérdést is, hogy személyesen volt-e dolguk az abortusszal a petíció elolvasása előtt. Bemelegitőnek szántam a kérdést, a témába való bevezetésnek, de arra is lehetőséget adott, hogy az emlékeken keresztül adalékokat, visszavetítést kapjunk a 70-es évek elejének férfi-női viszonyairól, arról, hogy ki, hogyan élte meg az abortuszt, a szexualitást (és magát a kort). A kérdés a nőket és férfiakat magától értetődően nem egyformán érintette, de az elmondottak alapján a férfiak is intenzíven élték meg. A válaszadók személyes érintettsége és motivációja is eltérő volt egyes esetekben. Az alábbiakban ezeket mutatom be.

Damásdi Diánának (Interjú 2015) nem volt abortusza, azon kevés szerencsések közé tartozik, akiknél a teherbeesések és a kívánt gyerekek száma egybeesett. De közvetett élményei, a barátnők szorongásai, félelmei beivódtak az életébe: „...a családokban és a baráti körömben végigéltem három olyan történetet, amikor segítenem kellett, tehát, hogy el kellett vetetni a gyereket, ilyen-olyan vagy amolyan ok miatt. És kálvária és káosz és fájdalom és sok pénz és remegés, rettegés volt mindig." ${ }^{2}$

Felidéz egy élményt is, amelyet ugyan a petíció aláirását követően élt meg, de amely, mint mondta, visszaigazolta számára a petíció aláírását. Az epizód megerősíti a fent idézett szorongásokkal és félelmekkel teli társadalmi kontextust, rávilágít a '70-es években jelen levő erôs intragenerációs szolidaritásra, és megmagyarázza, miért érezhették az aláirók, hogy az abortuszhoz való jog tényleges szabadság volt, hogy meg kellett védeni:

Volt egy nagyon jó baráti házaspár, Jenőnek [férjének] nagyon régi barátai, Erdélyben laktak. És megjelent a feleség, Mária, egy este nálunk azzal, hogy ő Ibusz úton van Romániából, de elszökött. A többiek elmentek Prágába, és óneki most [Budapesten] ki kell derítenie, hogy terhes-e vagy nem. Mert ha terhes, akkor abortusz kell, de ezt mind két nap alatt kell megcsinálni, mert visszajön a társaság Prágából, és neki csatlakoznia kell a buszhoz, és haza kell mennie, mintha mi se történt volna. Ha viszont nem terhes, azt is tudnia kell. [Romániában már maga az orvosi vizsgálat kérése önfeljelentéssel, rendőri

1 Az 1997. január 5-én a Csehszlovák Szocialista Köztársaság Szövetségi Gyűléséhez eljuttatott tiltakozó dokumentum Jan Patocka, Jiri Hajek és Václav Havelnek, a Charta szóvivőinek aláirásával (Puntigán 2017).

${ }^{2}$ Az idézett interjúk elérési helye: HU OSA 432, Körösi Zsuzsa interjúgyújteménye. 
vizsgálat alá kerüléssel volt egyenlő.] [...] És akkor egy olyan kálváriát jártunk vele végig, ami számomra azóta is az egyik legszörnyúbb élmény maradt. Mert ugye akkor nem volt ilyen, hogy fogsz egy tesztet és két perc múlva megtudod, hogy terhes vagy-e vagy nem, hanem egy békateszt volt csak és kizárólag, illetve hát semmi másról nem tudott a normál ember. És a Jenő éjjel belötyögtette a pisit a János kórházba, ahol én [...] be voltam jelentve, ugye 12. kerületiek voltunk, és ott valahogy elintéztük, hogy egy nap múlva megtudja az eredményt. De az már túl késő lett volna, hogy akkor keressünk nőgyógyászt, no Jenőnek sikerült valakit találnia a külső Dózsa György úton. Nekünk volt egy Trabantunk, két kisgyerekünkre az anyósom vigyázott [...] és ez borzalmas élmény volt, mert a pasi elvállalta [az abortuszt], és rögtön meg akarta csinálni. De, mondta neki Mari, 'bocsánat, most még nem tudom, hogy terhes vagyok-e’ És akkor a Jenő mondta, hogy ez egy lehetetlen alak, és hogy nagyon fél, hogy mi lesz ebből. És másnap reggel elmentünk az eredményért, és kiderült, hogy negatív. Óriási megkönnyebbülés, Mari egy órát zokogott, alig tudtam megnyugtatni, mert akkor kijött belőle az összes feszültség, és visszamentünk a pasihoz, mert, hogy máskor majd még szükség lehet rá, és a pasi majdnem megölte Jenőt meg Máriát, mert ő már fel volt készülve arra, hogy kap pénzt. És akkor Mari visszautazott.

Szebeny Jenő, Damásdi Diána férje (Interjú 2015) az abortusz más elsősorban a romániai tiltásából adódó -, jogi és egészségügyi vonatkozásait idézi fel. Egy olyan tárdadalom-képét idézi meg, amely a női testtel való önrendelkezést és ennek nők és férfiak részéről történő védelmét kriminalizálja: „Kifejezetten az az érzésem volt, hogy most [mindannyian] lemerültünk a bűnözésnek a szférájába, tehát a polgári életből átkerültünk a sötét oldalra."

Váradi Júliának (Interjú 2015) több abortusza volt, és nôi és emberi mivoltában érezte sértőnek, megalázónak, hogy a politikai hatalom az 1956-os forradalom hatására hét évig vállalt liberalizmusának hátat fordítva jogot próbál teremteni a magánszféra irányítására. Felháborodottan beszél arról, hogy

bárki, legyen az a politikai adminisztráció tagja vagy bármilyen grémium, megmondja nekem, hogy én mikor hány gyereket hozhatok a világra vagy lehetek vele terhes vagy elvetethetem-e azt a terhességet. De hát [...] végig kellett mennem azokon a dolgokon. Nem egy abortuszom volt, és egyik szörnyűbb volt, mint a másik, és nem csak magáért a dologért, hanem azért, mert [...] amikor már három gyerekem volt, akkor is el kellett mennem egy abortusz bizottság elé, ahol ült négy hölgy, akik szerintem férfit az életükben nem láttak, de ha láttak is, akkor attól nagyon megijedtek. És olyan hangnemben és olyan durván és olyan megalázóan beszéltek velem, hogy a végén én szégyelltem magam, hogy lehet, hogy tényleg valami csúnya dolgot müveltem? 
Karakán Melinda (Interjú 2015) gimnáziumi osztálytársnői története kapcsán a fogamzásgátlás eszközeivel nem rendelkező fiatal lányok szexualitáshoz való viszonyát idézi fel:

Az osztályomban volt négy lány, akikkel jóban voltam, akik elhatározták tizenhat éves korukban -, hogy megszabadulnak a szüzességüktől és lefekszenek, és - ez susmus formájában terjedt - a négyből egy teherbe is esett, és akkor ott megint a susmus, hogy hát abortusz. [...] Emlékszem, akkor ez nagyon kiborított. Ez a nagyon-nagyon rossz történet, ez az olcsó rossz női történet. [...] Hogy mondjam, biztosan lehet mondani egy olyan filmet, ahol ez úgy látszik, melyik volt az a Menzel film, Szigorúan ellenőrzött vonatok, a Viktória Freyával, szóval, hogy az öröm valahogy hiányzik a történetből. Nekem ez alaptörténet volt, amitől nekem az abortusz iszonyúan taszító dolog volt.

Karakán Melinda néhány hónappal az interjú után elmondta saját abortuszának rövid történetét. Ezt az epizódot írásban csatolta az interjú legépelt változatához. A személyes történet, paradox módon, nem hagyott benne olyan kínos, fájdalmas emléket, mint a korábban elmesélt esetek. A leírás ezentúl a nők intergenerációs szolidaritásának és háttér-motívumként a nemek közötti szexuális egyenlőtlenségnek a példájával is szolgál:

Most akkor elmesélem a saját rossz történetemet. [...] Erre csak mostanában jöttem rá, Zsuzsával beszélgetve. 1970-ben volt egy abortuszom, amit úgy éltem meg, ahogy hal úszik át egy karikán - a vízben, persze. Sehogy. Semmi ütközés. Föl sem vetődött bennem, hogy egy szerelemben fogant magzatot ki is lehetne hordani. És ebben nagy szerepet játszott ez az „olcsó női történet", amit azért kissé lefitymálva említek. A legprimitívebb módon lett nálam/általam is kezelve. A másik dolog, hogy az anyámat kértem, hogy legyen velem. Persze, nem másik dolog, összefügg az előzővel. Amiért a barátommal nem beszéltem meg, ugyanezért kértem az anyámat. Aki gond nélkül vállalta, és akivel soha, semmikor nem beszéltem a szexuális életről. Nem volt tabu, de nem-tabu sem volt. Ö édesen ápolt a mútét után. Amit könnyedén csináltam végig, szemben az Abortusz Bizottsággal, ami egy vészbírósággal ért fel. ${ }^{3}$

Kornis Mihályt (Interjú 2015) nem a női test vonatkozásában, hanem erkölcsi szempontból érinti az abortusz. Az apaságra önmagát alkalmatlannak férfiről és ennek következtében az embrió megöletése miatt érzett lelkiismeretfurdalásról, szomorúságról beszél. Noha a szexuális partnerek háttérben maradnak, abortusszal kapcsolatos érzelmeikről Kornis nem próbál nyilatkozni, a „menjél és szúrasd meg magad és nem kell a gyerek”

\footnotetext{
${ }^{3}$ Karakán Melinda kiegészítő jegyzet 2016.
} 
megfogalmazás valamit homályosan érzékeltet arról, hogy a kérdés egyik félnek sem semleges:

Többször előfordult az életemben, hogy lányok azt mondták nekem, hogy van egy gyerek a hasamban tőled, és te vállalod-e, és én abban a helyzetben voltam, hogy mindig azt éreztem, hogy nekem olyan csodálatos apám volt, aki egyáltalán nem akart író lenni, és egyáltalán nem gondolta, hogy neki bármi más dolga van az életben, mint hogy gyereket csináljon, és ezért én mindig borzadtam attól, hogy akkor ezzel a gyerekekkel ki fogok baszni, mert nyilvánvalóan nem akarom ezt a csajt feleségül venni, a gyerek meg fog születni, azzal millió izé lesz - miféle ember leszek én? Ha, ha olyan leszek, mint azok, akiket láttam már, ilyen múvészemberek, akik le se szarják a gyereküket, az lesz a baj. Ha meg ôvele foglalkozom, akkor egész életemben azt fogom gondolni, hogy azért nem lett belólem író, mert nem szántam oda magamat neki, tehát tulajdonképpen a gyereket gyúlölni fogom, de ezt nem fogom bevallani, tehát ez az egész, és akkor én mindig nagyon idegesen és dühösen azt mondtam „hányadik hétben vagy” és ha nem mondta, hogy a hetedikben, akkor aztán [mondtam] „menjél és szúrasd meg magad és nem kell a gyerek" és akkor a lányok mind halálosan megsértődtek, és meggyúlöltek. Nem mind, és nem volt ez olyan sokszor.

Az 1973-ban 17 éves gimnazista Márkus Piroskának (Interjú 2015), nem volt még se közvetlen, se közvetett élménye az abortusszal kapcsolatban, de félelmetesnek tartotta: „Azt gondoltam, hogy ez egy olyan dolog, amin remélem, hogy soha nem kell átmennem. Nem volt erkölcsi kifogásom ellene, de ugyanakkor egy ilyen mumusnak tủnt."

Dobos Evvának (Interjú 2015) egy Ikarusz gyári történet tolult fel emlékeiben. Azt mutatja meg, hogy a gyár női alkalmazottai mennyire kiszolgáltatottak lettek a terhességük következtében:

Az Ikarusz gyárban, amikor felvettek oda [1962 és 1968 között], volt egy megrázó élményem, ami kapcsolatban van a szóban forgó kérdéssel éspedig: a felvétel az úgy zajlott, hogy mielőtt egyáltalán szóba álltak volna velem, a felvételi irodán elküldtek egy nőgyógyászhoz, hogy kiderítse, nem vagyok-e titokban terhes. [...] Hát ez elég meglepő és megrázó volt. Addig nemigen fordultam meg nőgyógyásznál, úgyhogy ezt egy elég brutális dolognak láttam.

Külön tanulmány témája lehet az, hogy az Ikarusz párttitkára és a párttitkár felettesei tudtával történt-e a nők ilyen brutális „selejtezése” és a hivatalos népesedés-politika ilyen formában történő hallgatólagos de radikális szabotálása. A történet ismeretében érdekes lenne egy tanulmányban feltárni, hogy országos szinten milyen mértékben volt elterjedt ez a gyakorlat a 
termelésben és hogy kitől kaptak felhatalmazást a személyzeti felelősök a nők ilyen megalázására.

Betlen Anna (Interjú 2015) 1973-ban 20 éves volt. Neki az abortuszról a szexualitás terén uralkodó nem, vagy alig feltűnő, mindennapos, a társadalom minden szegmensét átható nemi egyenlőtlenség jut eszébe:

\begin{abstract}
Akkoriban még a fiúk, a fiúpartnereink esetében szó nem lehetett óvszer használatról. Tehát [...] nekünk, fiatal lányoknak eszünkbe sem jutott kérdőre vonni a férfi barátainkat, hogy miért nem akarnak óvszert használni, mikor az kevésbé káros mindenkire nézve, mint az akármilyen fogamzásgátló hormonális tabletta miránk nézve, hanem azt gondoltuk, hogy nem jók ezek a szerek, se nem elég biztonságosak, se nem elég ártalmatlanok, és ezért, amikor az embernek nem volt állandó partnere, akkor nem használta, akkor mást használt, és akkor már ki volt téve annak a veszélynek, hogy teherbe eshet. Úgyhogy a mi, hát nem túlságosan messzire látó szemléletünkben az, hogy az abortusz ott van a végén, az mind benne volt, ez a lehetőség. Úgyhogy [az abortusz elérhetőségének megszigorítása vagy megvonása] a szexuális szabadság korlátozását is jelentette. A szexualitáshoz való egyenlő hozzáférés korlátozását jelentette, akkori meglátásunk szerint.
\end{abstract}

\title{
Kié a szabadság?
}

A kérdést, hogy kié a szabadság, amely implicit módon felvetődik a fent idézett mondatokban, explicit módon két megkérdezett, Szil Péter és Betlen Anna veti fel. Egy harmadik interjúalany, Kornis Mihály (Interjú 2015), noha nem fogalmazza meg feketén-fehéren de megérteti, hogy az abortuszról, a szexuális, szerelmi partnerek véleményével, szándékával ellentétben ő, a férfi döntött. Ez a döntés, mondja, nem volt könnyủ, komoly lelkiismereti válságot okozott számára minden esetben: ,ahogy öregebb lettem, egyre jobban fájt az egész, és egyre mélyebb nyomokat hagyott bennem", de ez nem változtat azon a tényen, hogy az övé, a férfié volt az utolsó szó, ha lelki konfliktusokkal is járt számára; az abortusz az ő akkori, a pillanat által diktált érdekét, „szabadságát” szolgálta.

Szil Péter (Interjú 2015) az abortuszról, mint kényszer-eszközről beszél. Elmondása szerint rá személyesen ez nem vonatkozik. Az ő személyes életében ugyanakkor nem az abortusz, hanem a gyerek megtartása vált meghatározó traumás élménnyé a 21 éves korában létrejött párkapcsolatban. Ebben a kapcsolatban gyermeke született, anélkül, hogy ezt választotta volna, és hogy képes lett volna felvállalni az apa szerepet. Ez az a helyzet, amit Kornis elkerült a barátnők abortuszra „ösztökélésével”. Ugyanakkor, folytatja Szil, részese volt „a reprodukcióért semmilyen módon felelősséget nem vállaló férfiviselkedésnek.” 
Az előbb kérdezted, hogy nekem milyen motivációim voltak az abortusz petíció [aláírásában] és említettem két dolgot: a petícióban megfogalmazott aggodalmak plusz az, hogy [ez a petíció] az ellenzéki fellépésnek egyszerūen a része volt. És volt egy harmadik ok - ez jutott eszembe a szabadság szóról - az egésznek a szexuális forradalomhoz való viszonya. Azt hiszem, hogy az abortusz petíció része annak, ahogy Magyarországon a szexuális forradalom lecsapódott, és ami elsősorban [...] a gyakorlatban azt jelentette, hogy megszületett a szexualitáshoz való jog és a szexualitás szabadsága. [De] nem született meg a nemet mondás szabadsága. És ez alapvetően a férfiak szabadságát jelentette, és az abortusznak ebben fontos jelentősége volt, ugyanis [...] volt egy önös érdek is a férfiak részéről. Ezt kötöm össze azokkal a fájdalmas [női] történetekkel, amelyeknek én már akkor fültanúja voltam, és amikből még többet tudtam meg a későbbiek során. A mai véleményem szerint a férfiak részéről történő felelőtlen viselkedés miatt nők nem kívánt terhességbe lettek belekényszerítve vagy abortuszokba, amelyeket nem ők választottak.

Betlen Anna, közgazdásznak (Interjú 2015) 1995 és 2004 között a Munkaügyi Minisztérium Nőpolitikai Titkárságán, azután az Egyenlő Esélyek Titkárságán, majd a Szociális Minisztérium és Nőképviseleti Titkárságán a nők elleni erőszak és a nők foglalkoztatása volt a munkaköre. 2004 végén, emlékezik vissza Betlen, „az akkori szocialista kormányzat unta meg az egyenlő esélyek témát, és tett ki mindannyiunkat onnan, akik ezen dolgoztunk". 2005 óta emberjogi aktivista, szakpolitikus, a MONA és a több nőjogi civil szervezetet tömörítő Női Érdek munkatársa. Legfontosabb kutatási területe a nők elleni erôszak, a prostitúció és a nemek egyenlőségét szolgáló közpolitika, a gender mainstreaming. Kutatásokat vezet, lobbitevékenységet, szolgáltatásszervezést, képzéseket folytat a női egyenjogúsághoz kapcsolódó témákban. Hivatásként és elkötelezetten foglalkozik a nők egyenjogúságának problémáival, a megoldások elé tornyosuló akadályok lehetséges megszüntetésével. Próbál némi elörelépést kicsikarni az ennek nagyon ellenálló ország meglehetôsen konzervatív intézményeiben. 1973-ban a legfiatalabb alárók egyike. 2015-ben is, mint 1973-ban azt az abszurd jelenséget hangsúlyozta, hogy a politikai szférában férfiak döntenek arról, hogy engedélyezhetô-e az abortusz a nôk számára:

Egyetlen nő sem akar abortuszt. Senki sem megy önként abortuszra, az nem szórakozás egy nőnek. De nem az abortusz megtiltásával, hanem az abortusz feleslegessé tételével kell fellépni a nem kívánt terhességek ellen, meg egyáltalán, ez ellen a jelenség ellen. Én is így érvelek, és hát mind a két állitásom ellenkezésbe szokott ütközni. Az is, hogy a nők nem akarnak abortuszt, az is, hogy az abortusz nem a nők szabadságának a záloga, hanem a férfiak szabadságának a záloga az én véleményem szerint. Ma már így látom. És mind a tilalom, mind az engedélyezés a döntéshozatali fórumokon 
a férfiak között zajlik, és ahelyett, hogy feleslegessé tennék, tehát ingyenessé, elérhetôvé és változatossá tennék a fogamzásgátlás mindenféle módszerét, mind a férfiaknak, mind a nőknek, ehelyett azon tépik egymás haját a férfiak a parlamentben meg más döntéshozatali fórumokon, hogy szabad-e vagy nem szabad a nőket kés alá küldeni.

Beszélgetőpartnereimnek az abortuszról vallott 1973-as felfogását, pontosabban annak megidézését a következőkben lehet összefoglalni. Meg kellett védeniük az érvényben lévő jogszabályt annak ellenére, hogy látják, az abortusz rossz megoldás, a magyar társadalmi kontextusban nem garantálta sem a nők testükkel való önrendelkezését, sem a nemek közötti egyenlőséget. Mégis, mint utolsó lehetőség, lehetővé tette a nemkívánt terhességek megszakítását, igénybevételével elkerülhetővé vált nők, gyerekek, családok sorsának tönkretétele.

\section{A petíció aláíróinak motivációi: nőkért, gyerekekért, szegényekért, emberi jogokért}

Szebeny Jenő (Interjú 2015) az abortusz-jog megszigorításában a hátrányos helyzetben lévő nők helyzetének további romlását tartotta a legveszélyesebbnek. Ezt akarta megakadályozni a petíció aláírásával:

'69 óta dolgoztam [a Tömegkommunikációs Kutatóközpontban] [...]. Ott egy tömény injekciót kaptam szociológiából, [...] és a petíciót olvasva gyakorlatilag mozgósult bennem az a sokféle dolog, amit a társadalomról a szociológia mondott, alapvetően az, hogy egy olyan jelenséget, mint az abortuszt, nem lehet azzal szabályozni, hogy betiltjuk, mert akkor egyszerūen az a társadalmi réteg, amelyiket ez legjobban sújt, az elmegy az angyalcsinálóhoz vagy megöli a gyerekét vagy szörnyúségek történnek. Tehát amikor én ezt a petíciót olvastam, akkor bennem ez a friss tudományos élmény, [...] mozgósult, és ez határozta meg, hogy abszolút egyetértettem vele.

Betlen Anna (Interjú 2015) az 1956-ig tartó abortusztilalom demográfiai ártalmait, a gyerekeket, családokat, az oktatást érintő negatív hatását személyesen élte meg:

Én magam is Ratkó-gyerek vagyok, ezt nem tudom, hogy akkor [1973-ban] meggondoltam-e, de tudtam, hogy nagy népességrobbanással járt az abortusz szigorítása annak idején, és hogy ennek bizony káros következményei voltak ránk nézve. [...] Például nem jutottunk iskolához, ellátáshoz, állandóan többen voltunk, mint ahányan elfértünk valahol, ez nagyon feltűnő volt. Hát a mi generációnk számára ez egy folyamatos 
problémát jelentett, és jelent ma is a Ratkó-generáció tagjának lenni. Minket nem vettek fel gimnáziumba, negyvenvalahány fős osztályokba jártunk, én nem, nekem szerencsém volt, de a kortársaimnak igen, folyton mindenhonnan kiszorultunk, nem volt elég hely.

Az aláirókat 1973-ban nem tudtuk megkeresni, megkérdezni, miért írták alá a petíciót, de az MNL-ben sárguló lapokon itt-ott olvasható kiegészítő, kézzel vagy írógéppel írt spontán vélemények válaszolnak a kérdésre.

Legtöbb hozzászólás a nehéz lakás- és gyerekellátási viszonyokról, a nem kívánt születések okozta lelki problémákról és a szexuális felvilágosítás elégtelenségéről ír, amelyek orvoslását az abortusz-szabadság korlátozása előtt és helyett javasolják. Hat olyan hozzászólást idézek, amelyek túlmennek a petíció szövegének egyszerü megerősítésén, hangot adnak a józan észnek, ugyanakkor segítenek a 70-es évek mindennapi életének érzékeltetésében. Némelyikben a néhány személyes mondat mögött bonyolult emberi sorsok tárulnak fel.

Könczöl Csaba, foglalkozása az interjú idején muzeológus a Budapesti Történeti Múzeumban. Az elviselhetetlen lakáshelyzet, a gyermekellátás elégtelensége és a jövőben várható tiltott vagy megnehezített abortusz egészségügyi következményei ellen érvel. A lakáshelyzetről szóló bekezdés különösen jó betekintést ad arról az általános rossz közérzetről is, amely a 70es évek Kádár-rendszerét, a 30-as éveik elején járó fiatal családosok nyomasztó helyzetét jellemezte:

A mai lakótelepi lakások többségének alapterülete 45-55 $\mathrm{m}^{2}$ között mozog. A hely már két kisgyerekkel is szűkös, és a szülőktől nem luxus-, hanem normális emberi igényeik jelentôs részének feladását, társaság, külön szoba, stb. stb., követeli meg. De mi lesz, ha a gyerekek felnőnek? Általában már ma is 18-20 éves korukig otthon élnek. Négy-öt felnőtt ember számára ekkora lakás már csak börtön, ahol nincs mód se tanulásra, se olvasásra, se nyugodt pihenésre. Nem felelőtlenség-e perspektívikusan börtöncellaszerű, túlzsúfolt lakásokba kényszeríteni ezreket és százezreket? [...] Összefoglalva, amíg a családtervezés más módjai nem kapnak hatható támogatást és propagandát, és amíg a nem kívánt gyermekáldás a szociális nehézségek miatt egész családok tönkretételével jár, addig az abortuszt szükséges rossznak tartom, de a fenntartása mellett vagyok. ${ }^{4}$

${ }^{4}$ MNL MSZMP KB-PB 288.f.36/1973/34.ö.e. 189. lap. 
Gödrös Júlia, foglalkozása TV szerkesztő, az abortusz-szabadság korlátozásának emberjogi és szociális következményeit hozza fel, mint súlyos ellenérvet: ${ }^{5}$

A törvény megszigorításának terve az eddigi eredményeinkhez képest visszalépés [olvashatatlan javítás], amely nemcsak a nők, hanem minden ember legszemélyesebb jogát csorbítja a család tervezésében, személyes döntési szabadságában. A szexuális felvilágosítás jelenlegi fokán az abortusz törvény megszigorítása a véletlenül született gyermekek tömegét jelentené. Nem tudom, hogy a társadalom- és családtervezésnek ez a kényszerre alapozott formája - még ha az emberszaporításban el is éri célját - ugyanígy eléri-e az öntudatos, harmonikusan nevelt emberek szaporításában is? A szóban forgó törvény a csökkenő népességszaporodás okait nem szünteti meg, viszont közérzetbeli és egészségügyi ártalmai felmérhetetlenek. Az abortusz-törvény minden nemú megszigorítása ellen foglalok állást. ${ }^{6}$

Márkus Zsuzsa, foglalkozása mérnök, egy gyerekes egyedülálló anya, a gyereküket, gyerekeiket egyedül nevelő anyák helyzetét írja le. Még akkor is érdekes idézni, ha tudjuk, hogy még a legvérmesebb abortuszellenes lobbizók - és az MSZMP KB-ban nekik hangot adók is - az egyedülálló anyákat külön kezelték, többé-kevésbé mentesíteni akarták a szigorítás/tiltás alól. Legtöbbször egyébként rejtett eugéniai meggondolásokból, ugyanis. az egyedülálló anyák között nem a mérnökök voltak többségben, hanem a lobbizók számára nem kívánatos etnikai-társadalmi szegény rétegekhez tartozók:

A bölcsődei és óvodai férőhelyek száma felháborítóan alacsony, továbbá nincs megoldva az egyedülálló anya segélyezése arra az időre, amíg a gyerek beteg és nem mehet közösségbe. Jelenleg fizetés nélküli szabadságot biztosítanak a gyerek kétéves korától erre az időre az anyának, ami azt jelenti, hogy a hosszan tartó vagy gyakori betegség esetén se az anya, se a gyerek nem tud megélni. ${ }^{7}$

Rácz István, 21 éves, foglalkozása mûszerész, csak egy mondatot írt kék tollal a neve alá: „Tudom, mi az, amikor egy gyerek úgy jön, hogy senki nem várta és nem akarta.",

... Józsefné (olvashatatlan a vezetéknév), foglalkozása nevelőotthoni nevelő, szakemberként ír azoknak, akikről úgy gondolta, hogy el fogják olvasni a javaslatát:

${ }^{5}$ MNL MSZMP KB-PB 288.f.36/1973/34.ö.e. 190.lap

${ }^{6}$ MNL MSZMP KB-PB 288.f.36/1973/34.ö.e. 190.lap

${ }^{7}$ MNL MSZMP KB-PB 288.f.36/1973/34.ö.e. 169.lap

${ }^{8}$ MNL MSZMP KB-PB 288.f.36/1973/34.ö.e. 135.lap 
Mivel a születések száma adminisztratív úton történő emelése feltétlenül növelné az intézetekben nevelkedő gyerekek számát, az államnak újabb százmilliós nagyságrendű kiadásokat jelentene. Érdemes azon elgondolkodni, nem lenne-e helyesebb ezt az összeget, ill. ennek töredékét a prevencióra, vagyis a széleskörú szexuális felvilágosításra fordítani. Az anyagi tényezők mellett talán nem másodlagos az sem, hogy nincs jogunk nem kivánt, és ezzel eleve boldogtalan gyerekkorra itélt gyerekeket a világra erőszakolni. ${ }^{9}$

Brót Éva, foglalkozása MAFILM naplóvezető, önmagáról és édesanyjáról, a teljes abortusztiltás éveinek két áldozatáról ír:

23 éves vagyok. A Ratkó-korszaknak nevezett időszakban születtem, egy olyan törvény jóvoltából, mely az egész eddigi életemet befolyásolta. Anyám leányanyaként szült meg nagyon szegény körülmények között. Nehezen tartott el és nevelt fel. Az ô életét is eldöntötte és negatív irányba befolyásolta az én létezésem. Talán most az én sorsomat fogja befolyásolni a jelenlegi abortusztörvény módosítása, mert több lesz a negatív hatása, úgy a nôk szociális helyzetére, mint a születendő gyermekek fejlődésére nézve. ${ }^{10}$

Két újságíró, Ránki Júlia és Váradi Júlia számára az abortusz-jog, az egyéni, emberi - nem sajátosan női - szabadságjogok részét jelenti. Ránki Júlia (Interjú 2015) egy olyan társadalomban gondolkozott, amelytől nagyon távol voltunk 1973-ban, de ez az utópia megért egy ellenzéki akciót:

Nem lehet központilag meghatározni az emberek sorsát, hanem alternatívákat kell kínálni, és lehetőleg korszerủ, jól választható alternatívákat. Tehát, hogy ha valaki sok gyereket akar, akkor legyen elég bölcsőde és óvoda, ha pedig valaki nem akar gyerekeket, annak legyen meg ehhez az orvosi háttere. [...] Úgy gondoltam akkor is, és most is úgy gondolom, hogy ezt nem volna szabad másképp.

Váradi Júlia (Interjú 2015) a magánszférába történő állami beavatkozást érezte megalázónak nem csak önmaga, mint nő, hanem a férfiak számára is:

Engem az abortusz törvény, mint olyan konkrétan azért érdekelt, mert azt gondoltam, hogy megalázó, amit tesznek egy emberrel, nem egy nővel, hanem egy emberrel, hogy megmondják neki, hogy mikor lehet gyereke és mikor nem, hogy ahhoz mi köze van bárkinek. Ez felháborított, de még ez sem, mondom, nem nőként éreztem ebben a nagy problémát, hanem társadalmi kérdést véltem ebben megvitatandónak tartani, és azt gondoltam,

${ }^{9}$ MNL MSZMP KB-PB 288.f.36/1973/34.ö.e. 133.lap

${ }^{10}$ MNL MSZMP KB-PB 288.f.36/1973/34.ö.e. 113.lap 
hogy nem hagyom magam. A férjem mellettem állt egyébként ebben, mert pontosan ugyanezt gondolta. Ez rá nézve is ugyanolyan megalázó volt, mint rám, én így képzeltem ezt akkor is.

\section{A petíció aláíróinak motivációi: baloldali hagyomány}

Többek számára az abortuszhoz való jog a női egyenjogúság részét képezi, és ezt a szülők, a család által közvetített baloldali, kommunista vagy szociáldemokrata hagyomány tette magától értetődővé. Ez a baloldali hagyományából táplálkozó abortusz-pártiság játszott számukra alapvető szerepet a petíció aláírásában. Ami paradox a helyzetben, az az, hogy noha ez a meggyőződés az állam és egyeduralkodó pártjának szintén alapdogmája, többek között emiatt a meggyőződés miatt tekinti a párt és kormány a petíció szervezőit és aláíróit „ellenségnek”.

Betlen Anna (Interjú 2015) a női egyenjogúság eszméjét szinte az anyatejjel szívta magába, ez volt motivációi általános háttere:

Nekünk otthonról [kommunista szülők harmadik gyermeke] volt egy általános emberi jogi beállítottságunk, ezen belül női jogi beállítottságunk is. Kezdve azon, hogy az ember akkor is dolgozik és tanul, ha nő, vagy a mi esetünkben már föl sem merült, hogy ha esetleg férjhez megyünk, akkor fölvennénk a férjünk nevét, ha ez jelent valamit itt most - a mai generáció számára ez nem sokat jelent -, de akkoriban ez nem volt feltétlenül így. Tehát általában a női egyenjogúságról voltak elképzeléseink, ha nem is nagyon mélyek, és az abortusz megszigorítása egyértelműen azt jelentette volna a számunkra, hogy korlátozzák a szabadságunkat, mert - mi így gondoltuk akkor - a szexuális szabadság korlátozását jelentené.

Ez a családi háttér, ezek a családi értékek meghatározóbb szerepet játszottak Betlen Anna életében, választásaiban, mint a '70-es évek társadalmi valósága, amelyből a nemek közötti egyenlötlenség több elemével kénytelen volt együtt élni.

Bauer Tamás is (Interjú 2015) első megközelítésben a kommunista hagyományra hivatkozik, amikor személyes motivációiról beszél:

Azok a megfontolások, amelyeket ma úgy hívnak, hogy életvédő megfontolások, tehát hogy [...] a magzatnak is vannak jogai, ezek a megfontolások abban az időben [1945 előtt] a baloldali és liberális közösségben nem nagyon merültek föl, mondhatni egyáltalán nem. Ugye a kommunista mozgalom mindig is nőpárti, egyenjogúság-párti [volt] és [...] az abortusz szabadsága melletti álláspontot képviselt a Szovjetunió egész 
története során. ${ }^{11}$ A Szovjetunióban szabad volt az abortusz, a német kommunisták is mindig a szabad abortusz hívei voltak, [...] és a magyar kommunista mozgalomban [is] a [női] emancipációnak mindig nagy szerepe volt $[\ldots]$. Tehát itt volt egy nagyon határozott abortusz szabadság-párti tradíció, és amikor a Központi Bizottság meghozta ezt a határozatát, akkor [...] széleskörű ellenérzés volt ezzel kapcsolatban.”

Soós Károly-Attila is (Interjú 2015) is ,a régi baloldali hagyomány”-ra hivatkozik, noha nem tartotta magát baloldalinak se 1973-ban, se később. Ennek ellenére az MTA Közgazdasági intézetének KISZ-titkára volt. A háború előtti baloldali, illetve liberális irányzatok abortusz-párti meggyőződése annyira beléivódott, hogy a petíció aláirása számára is magától értetôdő volt.

Karakán Melinda (Interjú 2015) szülei a két világháború között a kommunistákkal szembenálló szociáldemokraták voltak, de az ô családjában ugyanígy élt a „régi baloldali hagyomány”. Melinda nem beszél a nemek közötti egyenlőség családi utópiájáról, hanem a szabadság mindent átható szelleméról, amelybe ez is természetesen beleértődött.

Jómagam gyerekkorát, a családom hangulatát, ahogy Betlen Annáét, szintén „a régi baloldali hagyomány” határozta meg. Kommunista szüleim kapcsolatában, a családi, baráti beszélgetésekben, vitákban a megfogalmazott és meg nem fogalmazott értékek egyik alapeleme volt a férfiak és nők közötti egyenlőség elve. Anyám szűcs szakmunkás volt, apámnak nem volt szakmája. Amikor anyám, apám helyeslésével 1953-ban napi nyolcórás munkája mellett beiratkozott a pedagógiai főiskola esti tagozatára, apám - kényszer- és konfliktusmentesen, emlékeim szerint örömmel, odaadással - három évre, anyám tanulmányainak befejezéséig, átvállalta a háztartás és óvodáskorú gyerekük nevelésének, ellátásának feladatait. Azt, hogy én, egyetlen gyerekük, az egyetemig fogom vinni tanulmányaimat, első osztályos koromtól hallottam barátaikkal, kollégáikkal és velem való beszélgetéseikben. Ez a családi eresztés nyilvánvalóan meghatározó volt a '70-es évek amerikai és európai feminista mozgalmak és feminista irodalom iránti lelkesedésemben, a férfiakkal kialakított kapcsolataimban, és a petíció-akcióban vállalt szerepemben.

Végül, bár a baloldal-jobboldal kategóriái nehezen alkalmazhatók a tudományos életben jelen lévő kortárs politikai konfliktusokra, itt érdemes megemlíteni, hogy az aláírók egy része, mint például Soós Károly Attila (Interjú 2015) számára a petíció aláírása a tudományos életben való állásfoglalás része volt. Azt gondolta, hogy aláirásával erôsítheti a liberális, Nyers Rezső által képviselt frakciót a dogmatikus, „munkás-balos irányzattal”

${ }^{11}$ Ez a megállapítás így nem állja meg a helyét; a szabályozás szolgai módon követte a Szovjetunió mindig aktuális abortusz-szabályozását. Az ‘50-es évek elején ott is tiltott volt. 
folytatott vitáiban: „Ez is arra sarkallt, hogy ebbe a buliba [az aláirásgyújtésbe] én beszállok." (Nyers Rezsőt a számos közvetett és közvetlen támogatás ellenére 1974-ben eltávolították a pártvezetésből.)

\section{A petíció aláíróinak motivációi: ellenállás}

Ahogy a bevezetőben szó volt erről, 1973 komoly válság éve volt: a hatalom az 1960-as évek második felében megnyilt gazdasági és szellemi reformlehetôségeket befagyasztotta, elhallgattatta a gazdasági reformban és a marxizmus és általában a szellemi élet megújitásában résztvevő értelmiségieket, közgazdászokat, történészeket, filozófusokat, szociológusokat, írókat, művészeket. Ezzel párhuzamosan egy általánosabb társadalmi ellenállás kifejezőivé váltak évrôl évre a március 15-i tömeges tüntetések, amelyeket a hatalmat csak a részt vevők elleni megtorlásokkal tudott kezelni.

Váradi Júlia (Interjú 2015) így emlékszik a petíció évére:

1973 volt az az év, amikor - talán már '72-ben elkezdődött, de '73 volt a csúcs -, amikor március 15-én, az akkori Március 15. téri zavargások okán a mi barátainkat, az én unokatestvéremet, sok hozzánk nagyon közel álló embert egyszer csak elvittek Baracskára. Ekkor volt az, amikor lezárták az írógépeket, ekkor volt az, amikor rendőrök flangáltak az utcán folyamatosan és mindenkit igazoltattak. Tehát nagyon feszült, nagyon-nagyon kellemetlen, rossz légkörre emlékszem vissza.

Ezzel párhuzamosan az egyetemeken a fiatal természettudósok, egyetemista, gimnazista diákok egy része is, főleg akiknek lehetőségük nyílt nyugat-európai kapcsolatokra szert tenni, olvasni a poszt-68-as mozgalmak irodalmát, egyre nyomasztóbbnak, kilátástalanabbnak, elfogadhatatlanabbnak érezték Magyarországon a politikai rendszert. Klaniczay Gábor (Interjú 2015) a bölcsészkar hangulatát idézi fel:

Negyedéves történelem szakos voltam, és [...] '73 egy olyan év volt, amikor sok minden történt. Akkor volt a Konrád-Szelényi ügy meg a Bencééknek a kirúgása [Bence György és Kis János állásuktól való megfosztása]. Ezek híre mind eljutott a bölcsészkarra. Ott volt egyszer Aczél György, 12 és feltettek neki egy-két kérdést pl. Harasztival [Miklós] kapcsolatban, aki akkoriban

${ }^{12}$ Erre utal Magyar György az MSZMP ELTE PB Titkára 1973. december 3-án elküldi Seres Lászlónak, MSZMP V. ker. Bizottság részére az ELTE-n „Aczél elvtárs látogatása alkalmából előzetesen összegyújtött, s hozzá továbbított kérdések” listáját. A párttagok is a lakáspolitika és a népesedéspolitika közötti ellentmondást feszegetik kérdéseikben. FBL-XXXV.10.c. 1973/18-27.ö.e.2. lap. 
éppen vizsgálati fogságban volt. Ebben az időben kialakult egy reformmozgalom a bölcsészkari KISZ szervezeten belül is, amely megpróbálta értelmes célokra felhasználni ezt a szervezetet, ilyen volt például a hátrányos helyzetű diákokat tanító 'Studium Generale'. '73 végén vagy '74-ben volt, hogy Atkári Jánost, aki ennek a reform-KISZ-nek volt a KISZ-titkára, leváltották, és utána jött egy bizonyos Nagy Pista, ha jól emlékszem a nevére, aki bement a bölcsészkari KISZ-irodába, ahol egy nagy Che Guevara kép volt a falon meg mindenféle ilyesmi. Körülnézett, és azt mondta - véletlenül ott voltam, ezért tudom -, hogy na most itt ezt a sok szemetet kidobjuk, és rendet csinálunk. Szóval akkor jött egy rendpárti újra kézbevétele a KISZnek. Mindenki elvesztette az illúzióit, hogy ott, legalábbis a KISZ-ben lehet valami értelmeset csinálni, de ez nem azt jelentette, hogy más területen is eltűntek volna a lehetőségek a cselekvésre és hát ez [az abortusz-petíció] is egy ilyen lehetőség volt.

Az abortusz-jog megszigorítása azt bizonyította számunkra, hogy a hatalom minden területen, nemcsak az értelmiségiekkel, hanem az egész lakossággal, köztük a nőkkel szemben is, a kemény kéz politikája mellett döntött.

Ezekben a konfliktusokkal teli, mégis kilátástalan években engem személyesen a dacosság minimalista életfilozófiája vezetett, amit úgy fogalmaztam meg magamnak, hogy akkor, amikor nem lehet semmit se tenni, akkor bármit meg lehet próbálni. A petíció ennek az elvnek a megvalósulása. Az, hogy egy ilyen nagyszabásúnak mondható akció lett belőle, bizonyítéka annak, hogy nem voltam egyedül ezzel az életfilozófiával: a bármi megpróbálása volt, hogy fogjuk szaván a népi demokráciát; cselekedjünk az alkotmányban lefektetett törvények szerint. Van az országnak parlamentje, vannak választott képviselők, adjunk nekik egy nemes feladatot az abortusz kapcsán: képviseljék választóik véleményét, vitatkozzanak és utána szavazzanak. A shakespeare-i filozófus-bohócok szerepét játszottuk kevés illúzióval, de a kihívás érzésének örömével.

Az 1973-as nyár találkozásai, vitái, utazásai vonattal, autó-stoppal izgalomban tartottak mindannyiunkat, a petíció szövegének íróit, aláírásgyújtőit. A bármıből valami lett. Történt valami, amit mi kezdeményeztünk, ami a mi terveink szerint valósult meg, amit az elejétôl a végéig együtt, az eredeti tervek szerint véghezvittünk. Kivételesen nagyszerü nyár volt egy nyomasztó korban.

A legtöbb szervező és aláíró számára az abortusz-jog melletti kiállás nem kívánt magyarázatot, az akeció motiválta őket elsősorban. A petíció megírásában, aláírásában, aláirások gyüjtésében az ellenállás, a véleménynyilvánítás egy addig ismeretlen, ki nem próbált formája öltött testet.

Szász Domokos matematikus (Interjú 2015), a petíciót megfogalmazók, és az aláírásgyűjtés mikéntjét megtervezők egyike volt; 
számára az abortusz-téma mellett az volt az igazán vonzó és új, hogy a Kádárrendszerrel való politikai szembenállásnak olyan formáját választottuk, amely a kezdeményező „pesti belvárosi értelmiségi csajok” ismeretségi körénél jóval nagyobb számú állampolgár véleményének is hangot adott, mert formailag, jogilag kikezdhetetlen akció lehetőségét nyújtotta. Ez tette lehetővé, hogy először a népi demokrácia történetében, az állampolgárok kollektíven a politikai cselekvés alanyaivá váltak: véleményükkel az országgyülési képviselőkhöz fordultak egy a sorsukat és az ország sorsát alapjaiban érintő kérdésben. Szász szavaival:

Az egészet azért tartottam érdekesnek, fontosnak, mert hát ugye [...] ismertük, hogy milyen ez a rendszer, ebben a rendszerben a civil tiltakozásnak, a polgári tiltakozásnak nem nagyon volt helye, és nem nagyon voltak példák rá. Tehát olyan szempontból volt nekem ez a dolog rokonszenves, hogy végülis egy bizonyos fokig szinte kikezdhetetlen [...], nagyon szerencsés forma volt az, amit kitalált a társaság: [...] állampolgárként fordulnak az emberek az országgyúlési képviselőjükhöz, és megkérik hogy stb. stb.; [...] én [a petíciót] elörelépésnek tartottam ebben az irányban, fontos lépésnek tartottam.

Klaniczay Gábor (Interjú 2015) is a véleménynyilvánítás határainak tágítását tartotta vonzónak a petíció-akcióban:

Az [...] abortusztilalom újra bevezetésének veszélye elleni petíció annyiból tûnt érdekesnek nekem, hogy megpróbálta a létező politikai kereteket olyan módon használni, mint hogyha azok tényleg egy képviseleti demokráciának a keretei lettek volna, ami érdekes játéknak tûnt. Ugyan nem volt nagy bizalma senkinek, hogy ez mûködni fog, de ki lehetett próbálni; az volt az egészben az érdekes, hogy mi lenne, ha kipróbálnánk, és erre meglepően sok aláírás jött össze. Már csak ezért is érdemes volt, mert ez valamilyen módon egy új véleménynyilvánítási formát vezetett be.

Lángh Júlia, Váradi Júlia és Csákó Mihály számára a politikai cselekvésvágy kiélése, ennek élvezete egyfajta „,szelepnyitás” volt a fontos és izgalmas.

Lángh Júlia (Interjú 2015) szerint: „Az végülis mégiscsak tarthatatlan [...], hogy állítólag meg fogják szigorítani az abortuszt, ez ellen valamit tenni kellene. [...] Én csak egyszer voltam ott, a fogalmazás nem igazán érdekelt, az akció érdekelt, mert az magától értetődő volt, hogy valamit csinálni kell.”

Váradi Júlia (Interjú 2015) így beszél erről a cselekvésről:

Én akkor pont huszonöt éves, és már két éve a Magyar Rádiónak voltam oszlopos munkatársa [voltam] [...]. Már éppen megszületett az első gyerekem és - próbálok pontosan visszaemlékezni - nem tudom, hogy egy 
abortuszomat követően vagy azt megelőzően került a kezembe a petíció. [...] Amikor ez a petíció elérkezett hozzám, akkor úgy éreztem, hogy végre lehet valamit csinálni. Tehát az aláírás nem volt kérdés. [A március 15-i tüntetések után] elvitték a kollégáimat Baracskára, volt olyan kollégám, akit azért vittek el, mert a Múzeum körúton sétált egy táskával a vállán, és abban a táskában, azt feltételezték, hogy fényképezógép van, nem is volt benne, csak azt hitték, megpofozták, és elvitték. Tehát azt gondolom, hogy ez valamiképpen talán a lázadási vágyunknak egy ilyen icipici lehetősége volt, valami szelepet kiengedtünk ezzel.

Csákó Mihály (Interjú 2015) a cselekvés keltette örömre emlékszik, arra, hogy azokban az unalmas, álmos években hirtelen felébredtünk, hirtelen cselekedtünk:

CS.M.: Jó buli volt... Volt, volt benne valami ilyen...

K. ZS.: Brahis?

CS. M.: igen, igen, hogy most csinálunk valamit, és az, az azért jó, ha az ember végre csinál valamit.

Sokak számára azonban kizárólag az akció szimbolikus jelentősége volt a fontos, a petíció tartalma megítélése háttérbe szorult. Több aláíró egyébként azért nem kívánt interjút adni 2015-ben, mert ma nem ért egyet a petíció tárgyával - és talán már 1973-ban sem értett egyet az abortusz-jog védelmével. A petíció-akcióban való részvétellel, a politikai rendszerrel való szembenállásukat akarták kifejezni.

Kornis Mihály (Interjú 2015) elfogadta interjú-kérésemet, noha az abortusz kérdése nem volt egyértelmú számára, és ma sem az. Motívációi összetettek, többek között a cselekvés, a hatalommal való szembenállás lehetősége izgatta, a cselekvés mámora, álomszerűsége hajtotta. „Ebben az ügyben engem nem az abortusz érdekelt, hanem a hatalommal való szembeállás lehetôsége, a puszta ténye annak, hogy én ezt meg merem csinálni..."

Heller Ágnes (Interjú 2015) szerint pedig az akció jelentősége civil jellegében rejlik, abban, hogy ez volt a háború után Magyarországon az első civil megmozdulás:

Nem volt kérdés, hogy mi a tartalma, hanem a tartalomtól függetlenül, a funkció volt [fontos], hogy az állampolgárok, a honpolgárok összejönnek, és egy petíciót intéznek, és ez nem egy formális szervezet keretében és nem is Kádár Jánoshoz intézett személyes levélben történik, hanem a képviselőkhöz szóló általános levélben, amihez aláírásokat gyúijtenek. [...] Ez [...] civil kezdeményezés volt. 
Dalos György (Interjú 2016) egyenesen úgy véli, hogy a petícióban nem nőkérdésről, hanem a rendszer elleni állampolgári tiltakozásról volt szó. A motivációk között az ellenzékhez való tartozás megmutatása is fontos helyet kapott többeknél. Márkus Piroskának, Szil Péternek, Kornis Mihálynak a nem egyedüli, de az elsődleges motivációt jelentette. „Bármit” aláírtak volna, amivel a Kádár-rendszerrel való szembenállásukat, az ellenzékiekhez füződő barátságukat bizonyíthatták vagy megerősíthették, amivel kiérdemelhették, hogy az ellenzék befogadja őket. Betlen Anna is (Interjú 2015), egy másik kérdésre válaszolva az interjú közepén, átértékeli a korábban mondottakat, nem a nôkérdést tartotta elsődlegesnek ô sem, hanem a rendszerrel való szembenállást:

Nekem az a petíció akkor egyike volt azoknak az ellenzéki megnyilvánulásoknak, amelyek ezután sorozatosan következtek, és amelyekben vagy részt vettem, vagy nem, attól függően, hogy elértek-e engem vagy sem. Ez [a petíció], noha mondom, mélyen egyetértettem [vele] és mélyen bennem volt a nők egyenjogúsága iránti érzékenység, [...] de nem volt tudatosan viszonyom hozzá akkor, inkább az ellenzékiség meg a rendszer elleni közös fellépésnek az igénye volt bennem akkor.

Márkus Piroska (Interjú 2015) büszke volt, hogy az idősebbek bevették őt a társaságukba, megbíztak benne, értékelték okosságát, bizonyos mértékig felnőtté avatták:

Az az igazság, hogy elég sok témával kapcsolatban nagyon-nagyon szívesen mozdultam volna, tehát lehet, hogy ha a petíció tíz másik témával foglalkozott volna - ha egyetértettem volna a témákkal, ami valószínű, ha ebből a társaságból jön -, benne lettem volna, mert számomra a legeslegfontosabb dolog az egészben az volt, hogy egy tiltakozásnak a része vagyok. [...] Nekem az volt fontos, hogy teszek valamit a nagyon elnyomó rendszer ellen."

Szil Péter (Interjú 2015) azon a nyáron lépett 22-ik évébe, „kistestvére” volt egy ismert ellenzéki írónak, bátyján keresztül sokakat ismert az ellenzékben; mindennel azonosult ,abban az időben, ami az akkor már ellenzékinek minősülő társaságban mozgott.”

Kornis Mihály (Interjú 2015) - mint annyi írásában - 1973 nyarára is nem kevés iróniával emlékezett vissza 2015-ben. Petri Györgynek, ki mentora volt, barátsága, bizalma mindennél fontosabb volt Kornis számára, és amolyan vizsga-helyzetnek érezte a petíció aláirását és aláirások gyüjtését, aminek mindenképpen jelesen akart megfelelni. Az ellenzékbe való befogadása volt a tét: 
Egy szó mint száz, egyszer szerintem a Gyuri, mintegy ajándék- vagy megtiszteltetésszerűen közölte velem, hogy meg fog keresni egy Körösi Zsuzsa nevú csaj és alá akar majd íratni veled [...] egy úgynevezett abortusz kérvényt vagy petíciót, és evvel kvázi bizonyíthatod - bár ezt nem mondta ki, de így, ilyen volt az akusztikája annak a felajánlásnak -, hogy ha te valóban ezt a margó életet választod, akkor írd alá. [...] Mire én akkor felajánlottam neked, aminek te nagyon megörültél, és csodálkoztál, hogy én erre hajlandó vagyok, én viszont kurvára dolgoztam azért, hogy engem befogadjon az ellenzék, hogy én nemhogy aláirom ezt a papírt, hanem hajlandó volnék bevinni a filmgyárba és a filmgyár büféjében - ugyanis én mint rendező bejáratos vagyok - odamegyek majd szépen a Csoórihoz meg a Kósához, akik abban az időben a fiatal, hangadó filmművészeknek számítottak és mindent együtt csináltak, és ők voltak olyan hírben az én butuska fejemben, hogy ők hajlandóak volnának valamilyen vagányabb dologba is belemenni...

Damásdi Diana (Interjú 2015), Karakán Melinda (Interjú 2015) és Sólyom András (Interjú 2015) az aláírásgyúitő személyes tekintélyének vagy a hozzá füződő barátságának tulajdonítja, hogy aláírta a petíciót, ami szintén az ellenzékhez való tartozás bizonyításának affektív gyökerét mutatja.

Összefoglalva, beszélgetőpartnereimnél a petíció-akcióban való részvételben a feminista töltet, ezen belül az abortusz-jog védelme sokaknál nem volt se az egyetlen se a központi indíték, sőt több esetben teljesen hiányzott. Egyetértés a feminista kezdeményezők, aláirók és aláirásgyűjtők között abban volt, hogy mindannyian azt remélték, hogy nevükkel, aláírásukkal, aláírások gyújtésével, civil kiállásukkal hozzájárulhatnak a 70-es évek társadalmi valóságának, a privát tértől való megfosztottságnak (lakáshiány), a gyereküket egyedül nevelő anyák és általában a nők munkahelyi problémáinak, a férfi-nő kapcsolatoknak, a szexuális szabadság egyenlőtlenségének az orvoslásához. Többüknek a legfontosabb az volt, hogy alkalmuk nyílt a politikai rendszer kritikájára, a rendszerrel való szembenállásuk kifejezésére.

Abban is megegyezett a kezdeményezők gárdája és az 1553 aláíró, hogy - ellentétben a hatalom összeesküvés-koncepciójával - nem törekedtek a politikai rendszer megdöntésére. Ellenzéki magatartásuk a demokráciának próbált konkrét jelentést adni azzal, hogy az Alkotmányban biztosított lehetőségeket kihasználva, az érvényben lévő jogszabályok szövegével összhangban, egy meglévő szabályozás védelméert, egy korábbi jog megörzéséért vállalták a részvételt egy kollektív akcióban. 


\section{A petíció aláíróinak motivációi: önrendelkezés a női test felett}

Interjúim során mindenkitől megkérdeztem, hogy 2015-ben, több, mint negyven évvel később, mit gondoltak a petíció szövegéről. A válasz néhány stiláris kritika, a szöveg ,jólneveltségén” túlra vonatkozó kritikán túl - egyöntetű volt: mindenki vállalta, ma is aláirná a petíciót. Szil Péter (Interjú 2015), az interjúsorozat első megkérdezettje is, de hiányolt a szövegből egy számára fontos érvet, a nők testükkel való önrendelkezési jogát.

Miért maradt ki ez a fontos elv a szövegből? A feminista kezdeményezők megfeledkeztek volna erről az érvről? Nem valószínủ, hiszen ez volt az egyik problematika, amely a '70-es évek nyugat-európai, amerikai feminista mozgalmaihoz kötötte őket. Sajnos ma nekem sincs emlékem arról, hogy ezt a kérdést megvitattuk-e vagy sem a szövegírás óráiban. Talán mindazok, akik részt vettek a petíció szövegének megírásában, de 2015 nyarán nem akartak az 1973-as év epizódjába visszacsöppenni, egyszer majd lesz kedvük, vagy felidéződnek emlékeik és beszélnek majd erről.

A Szili megfogalmazta kritikára reflektálva, a vele készült interjút követően belevontam ezt a kérdést. Heller Ágnes (Interjú 2015) azt gondolta, hogy a nők testükkel való önrendelkezési joga 1973-ban Nyugat-Európában igen, Magyarországon nem volt releváns, aktuális kérdés, ezért ezt ma „számon kérni” a petíciótól „,történelmietlen” lenne. Mások is így vélekedtek. Én azt gondolom, hogy a kérdés igenis releváns volt. Ugyanannyira, mint azokban a nyugat-európai országokban, például Franciaországban és Olaszországban, ahol - Magyarországgal ellentétben - az abortusz 1973-ban tiltott volt. Ismétlem, itt nem emlékeket idézek fel, hanem valószínűsítek. Valószínűnek tartom, hogy erre a jogra való hivatkozás opportunista okokból maradt ki a szövegből, és itt az „opportunista” szót nem pejoratív felhanggal használom. A célunk az volt, hogy egy olyan szöveget véglegesítsünk, amelyet minél nagyobb számú nő és férfi készen áll aláirni, és tudtuk, interiorizáltuk, hogy emiatt ennek az érvnek ebben a petícióban nem kell szerepelnie. A petíció sikere, az 1553 aláírás igazolja-e opportunizmusunkat? Sajnos a petícióakciónak nem volt folytatása, így ez a kérdés sem került be a köztudatba egészen a '90-es évekig először a Feministák Egyesületében, később a $\mathrm{NaNe}$, a Patent majd a Nőkért Egyesület tevékenységében. ${ }^{13}$

${ }^{13}$ Forrásom, Acsády Judit 2017. február 17-i email-je „Igazad van, én is úgy látom, hogy nem tematizálódott a nők testükkel való önrendelkezésének a joga a közéletben Magyarországon. Pedig nagyon sok olyan mozzanat volt, ami miatt ez fontos lett volna, a reprodukciós jogok mellett, például a nőgyógyászati gyakorlatok lekezelő volta, a szülészeteken való méltatlan bánásmód (ez a kérdés hetvenes években érdekes módon megjelent az akkori orosz feministáknál), de ide tartozna a bántalmazás kérdésköre is, ami ugye tabu téma volt korábban. Szerintem mindez először a kilencvenes években merül föl a rendszerváltás után a Feministák Egyesülete, majd a NaNe tevékenységében, később nagyon fontos hanggá vált ez a téma a 


\section{A Belügyminisztérium korabeli értékelése: a petíció politikai jelentősége}

Mint az első részben már említettem, a Magyar Nemzeti Levéltárban (MNL) megtalálható Kornidesz Mihálynak, az MSZMP KB tudományos, kulturális és közoktatásügyi osztálya vezetőjének elemzése a petícióról. Az 1973. október 4-én íródott elemzés elismeri, hogy a petíció legtöbb érve felmerült a KB belsô vitáiban is. Mivel a vitát a KB lezárta és döntött, az volt a stratégia, hogy a petíció tartalmával nem fog foglalkozni. Ha nyilvánosan mégis szó esik róla, akkor ellenségesen, a jóhiszemú állampolgárok megtévesztésére kitalált érveknek lesznek minősítve.

Ezek a kérdések a határozat előkészítése során is felvetődtek, s a döntés mérlegelésük után történt. Ezért változatlanul azt javasoljuk, hogy a Kormány október 11-i ülésén a szükséges döntést hozza meg a jelenleg érvényben lévő abortusz-rendelet módosítására. ${ }^{14}$

Az elemzés ennek ellenére kitér a petíció „valóságtól elrugaszkodottnak" tekintett néhány követelésére, például arra, hogy egy gyermek után is járjon családi pótlék, hogy hat évre emeljék fel a gyermekgondozási segélyt, hogy ez utóbbira ne csak az anya legyen jogosult, hanem az a személy is - apa, nagyszülő vagy más családtag -, aki a kisgyermek otthoni gondozását vállalja. Az elemzés mind a három érvet magától értetődően elutasítja. Az első kettő a népesedéspolitika költségvetését érinti, míg a harmadik elutasításának ideológiai oka van. A nők nemi-társadalmigazdasági megkülönböztetésének rendszerében a gyermek $=$ teher $=$ kizárólag az anyákra kiosztott teher. Ennek megkérdőjelezése lett volna a petíció szellemének elfogadása, annak a gondolatnak az elfogadása, hogy a gyermek = élvezet és teher = nemek, generációk megosztott élvez̨ete-terhe kell, hogy legyen. Erre a paradigma-váltásra nem volt felkészülve az ország vezetése.

Ha az MSZMP-iratokban a petíció tartalmáról több szó nem is esik, annál többet foglalkoznak a kezdeményezők, a szervezők és a tanácsadók személyével, azoknak a rendszerrel való krónikusnak nyilvánított szembenállásával:

PATENT Egyesületnél, és a NŐKÉRT Egyesületeben (Antoni Rita csoportja). A feminizmus első hullámában a századfordulón is beszéltek a feministák a szexualitásról, fontosnak tartották a szexuális nevelést (ehhez mondjuk sok támogatást nem kaptak), felléptek a bántalmazás, a prostitúció és a leánykereskedelem ellen. Bár a történelem elfújta mindazt, amit ők képviseltek, ezek mostanában kerülnek csak újra előtérbe az archív anyagok kapcsán.”

${ }^{14}$ MNL-MSZMP-KB 288.f.36/1973/34.ö.e. 43-44. lap. 
A tartalmi vonatkozásokon túlmenően a beadványnak politikai jelentősége is van. A beadvány szerkesztői tudatos politikai ellenfeleink közül kerültek ki. (A beadvány szerkesztésében és az aláirásgyüjtés megszervezésében részt vett az 1968-ban maoista összeesküvésben elítélt Pór György és felesége [Körösi Zsuzsa]. Az aláírásgyűjtés tervét megbeszélték Fehér Ferenccel és Heller Ágnessel; terjesztésében a jóhiszeműek mellett közremúködött Konrád Júlia, Eörsi Istvánné és Szelényi Ivánné; az aláírók között szerepel Hegedűs András, és megtalálhatók más politikai ügyek szereplői is.) Szándékuk nyilván az volt, hogy ezt a módot is felhasználják politikai különvéleményük meghirdetésére és csatlakozók toborzására. A beadvány a tiltakozás mellett több tetszetős javaslatot is tartalmaz népesedési helyzetünk javítása érdekében, mely a jószándékú aláirók számára vonzóvá tette a beadványt. ${ }^{15}$

A résztvevők elemzésében, Kornidesz Mihály október 4-i MSZMP KB jelentésében megemlíti, hogy „Pór György és felesége az aláirásgyűjtés tervét megbeszélték Fehér Ferenccel és Heller Ágnessel.” Ez az állítás arra enged következtetni, hogy a KB kapott a Belügyminisztériumtól besúgói információt az aláírásgyưjtésrôl. Ugyanis, ha nem besúgók - pontatlan jelentése, hanem Heller és Fehér lakásának lehallgatása lenne a forrás, akkor Pór György neve itt nem szerepelne, mivel ô nem volt jelen a két filozófussal való találkozásunkon. Csákó Mihály (korrektori jegyzet) egy másik értelmezést is elfogadhatónak tart:

Ez teljesen logikus érvelés, de nem elég erős. Szerintem a forrástól függetlenül muszáj volt téged [K.ZS.] névtelen feleséggé visszaminősíteniük és egy [ismert] névhez kapcsolniuk, különben nem értették volna az elvtársak, miféle Körösi Zsuzsa? - Szerintem ez is egy lehetséges magyarázat, de a kettő együtt is futhat.

Mint a tanulmány első részében bemutattam, süketek vitája folyt a Párt és a Kormány illetve a népességpolitikai célkitűzéseiket bojkottáló „,nép”, „lakosság”, „felelőtlen nők”, „lakással rendelkező felelőtlen házaspárok” stb. között. Az 1972 októberében hozott döntés a kudarc elismerése: mivel „,nem sikerült előbbre jutni”, a sokgyerekesek negatív megítélésében a valláserkölcsi beidegződések tovább élésében, pl. a lányanyák elítélésében, a gyerekkultusz fokozásában, ${ }^{16}$ a hangsúlyt a továbbiakban a párt-és-kormány a nevelésre, a meggyőzésre fekteti - valamint módosítja az abortusz szabályozását, megszigorítja azoknál, akiknél indokolatlannak tartja anyagi szempontokból.

Süketek vitája folyt a Párt és a Kormány és az orvostársadalom között is. Ez utóbbi saját szakmai csatornáin kollektíven nem tiltakozott, azonban

${ }^{15}$ MNL MSZMP KB 288.f.36/1973/34.ö.e. 44. lap.

16 MNL MSZMP KB-PB 288.f.41./191.ö.e. 19. lap. 
többen egyénileg negatív véleményt nyilvánítottak az abortusz-jog megszigorításával szemben. Vezető szülészeket, nőgyógyászokat említ Kornidesz 1973 októberi elemzésében: „A terhesség művi megszakítása engedélyezésénél tervezett szigorításokat ellenzik egyes vezető szülészek is", írja. Név szerint kiemeli Dr. Zoltán Imre egyetemi tanárt, az Országos Szülészeti és Nőgyógyászati intézet igazgatóját, akinek nevét már idéztük az I. Részben a Népszava 1956 májusában megjelent cikke kapcsán. Dr. Zoltán 1973-ban ismét kiáll az abortusz-jog mellett; írásban küldte el az Egészségügyi Minisztériumnak a szigorítással és tiltással való egyet nem értését. Kornidesz megemlíti, hogy Dr. Zoltán Imre „érvei megegyeznek az aláírásgyüitőkéivel”. Azt is megtudjuk, hogy „Dr. Kovács András docens, Dr. Zoltán helyettese lemondott állásáról lelkiismereti motivációkkal." ${ }^{17}$

1973. október 9-én keltezett féloldalas, a feladó és a címzett megjelölését nem tartalmazó feljegyzésből megtudjuk, hogy

A Politikai Bizottság [...] a beadványt és az aláirásgyüjtést pártellenes lépésnek minősíti. Felhívja az illetékesek figyelmét arra, hogy ezzel így foglalkozzanak. Az aláirók között található párttagokkal megfelelő módon beszélni kell eljárásuk helytelen voltáról. ${ }^{18}$

Egy 1973. december 12-én keltezett, az MSZMP Budapesti Bizottsága Propaganda és Mûvelődési Osztályától származó feljegyzés már az aláirók beazonosításáról tanúskodik. Pataki János küld Kornidesz Mihálynak egy féloldalas feljegyzést a népesedéspolitikai aláirásgyújtésről. A mellékletben olvashatjuk a párttag és párton kívüli értelmiségiek részletesebb listáját és a velük lefolytatott beszélgetéseken történt megfigyeléseket. A listán neves írók, költők, filozófusok, szociológusok, közgazdászok, filmesek, színészek, pszichológusok nevei sorakoznak: Gyárfás Miklós, Hernádi Gyula, Kertész Ákos, Ladányi Mihály, Császár István, Bacsó Péter, Mészáros Márta, Biró Yvette, Berek Kati, Gábor Miklós, Tordai Zádor. Sós Vilmos, Könczöl Csaba, Ludassy Mária, ,akik a május 8-i PB határozata miatt léptek ki a pártból”, Mérei Vera és Mérei Ferenc, „akit ellenforradalmi tevékenység miatt elítéltek”, Bondár Éva és Bauer Tamás, „akik az elmúlt hetekben nem pártfórumokon [...] kifejtették a népesedési határozattal szembeni oppozíciós álláspontjukat". ${ }^{19}$

1974. január 29-i dátummal, Medve László titkárnőjének írt feljegyzésében olvashatjuk, hogy „A mellékelt anyagok a népesedéspolitikai

17 MNL MSZMP KB Tudományos Közoktatási és Kulturális Osztály jelentése 288.f. 36/1973/34.ö.e. 46. lap.

${ }_{18}$ MNL MSZMP KB 288.f.36/1973/34.ö.e. 57. lap.

19 MNL MSZMP Budapesti Bizottsága Propaganda és Művelődési Osztály 288.f.36/1973/34.ö.e. 59-61. lap. 
határozat elleni aláirásgyüjtésével kapcsolatosak, [...] a II. Félévben Agit. Prop. előterjesztést kell készíteni.” ${ }^{20}$ Az említett „mellékelt anyagok” az aláírók további, folyamatos feltérképezését tartalmazza. Ebből megtudjuk, hogy azonosításuk ekkor még nem fejeződött be, de már látták, hogy Budapesten az I., II., III., V., VI., VII., VIII., XI., XIII., XIX. kerületekben, sok fiatal értelmiségi és diák, sok szociológus, újságíró, muzeológus, filmes, könyvkiadói dolgozó, közöttük kevés párttag, írta alá; elenyésző a munkások száma állítja a melléklet. Ugyanitt olvashatjuk, hogy a Magyar Rádió és Televízió (MRT) pártbizottsága megnézte az aláírásokat és „folyamatosan foglalkozik az aláirókkal", az egyetemi pártbizottságoknak megküldik a petíciót aláíró egyetemi oktatók (párttagok és párton kívüliek) névsorát; javasolják „,hogy az Okt[atási] igazgatóság is nézze meg, hogy az aláírók közül kik oktatnak az intézményben" 21

Medve megnevezi azokat az oktatási és kulturális intézményeket is, ahol több munkatárs szerepel az aláirók között, illetve azok párttagságát is: Közgazdaságtudományi Intézet (11 aláiróból 10 párttag), Kossuth Könyvkiadó, Medicina Könyvkiadó („sok aláíró”, de csak egy párttag), Filozófiai Intézet (4 aláíró), ELTE (17 aláiró), MUOSZ és az Írószövetség „erösen érintett az aláirások szerint” (11 aláíró). Végül, noha számot nem közöl, említésre érdemesnek tartja a Lapkiadó Vállalatot, a Móra könyvkiadót, az Orvostudományi Egyetemet, a Magyar Rádiót és Televíziót, és a Budapesti Múszaki Egyetem Filozófiai Tanszékét.

Külön figyelmet szentel Medve a XI. kerületnek, ahol „elsősorban a lakótelepeken folyt aláírásgyújtés”, valamint néhány kiemelt: 5 színésznek (nevek nélkül), a Hamburger családnak - Hamburger Mihály, Hamburger Péter és nejeik, „a Tanácsköztársaság népbiztosának családja” - és az „ellenforradalmárok"-nak megbélyegzett Litván Györgynének és Mérei Verának. ${ }^{22}$

Összegezve, az első, október elejei KB-elemzés majd a későbbi jelentések, feljegyzések, a politikai rendszerrel való szembenállásról beszélnek. „Megállapítható, hogy azok, akik politikai ellenzékként léptek fel eddig is, ezt az alkalmat is felhasználták politikai demonstrációra. Megtalálható köztük a „korcsulai”, a Hegedüs-féle csoport, [több] 1956-os ellenforradalmár is.”23

Fontos beszélni azokról az aláirókról is, akik nem voltak közvetlen kapcsolatban a fenti értelmiségiekkel. Róluk a KB elemzői nem, vagy alig ejtenek szót. Sok segéd- és szakmunkás, ápolónő, óvónő, gyermekgondozó és csecsemőotthonok dolgozója szerepel az aláírók között. A Medve László által

${ }^{20}$ MNL MSZMP. Budapesti Bizottsága 288.f.36/1973/34.ö.e. 79. lap.

${ }^{21}$ MNL MSZMP. Budapesti Bizottsága 288.f.36/1973/34.ö.e. 84. lap.

22 MNL MSZMP. Budapesti Bizottsága 288.f.36/1973/34.ö.e. 89. lap.

${ }^{23}$ MNL MSZMP. Budapesti Bizottsága 288.f.36/1973/34.ö.e. 89. lap. 
felsorolt tíz kerület fele szociológiai szempontból szegény és munkáskerület; megtudjuk, hogy az óbudai hajógyárból külön listát kapott a kerület parlamenti képviselóje. Medve kiemeli Kalmár György nevét az aláírók között, nyilvánvalóan azért, mert a Panyova Goldberger Pamutnyomó KISZ-titkára volt. ${ }^{24}$ A petícióról kialakult kép ezeket az aláirókat az évek során nagyjából kiradírozta, és - a Belügyminisztérium és az MSZMP KB konstrukciójával összhangban - a petíciót mint elszigetelt értelmiségi akciót, sőt egy-két „Összetartó” (ez volt a BM III/III-4-es alosztályán a rólam és Pór Györgyről vezetett dosszié neve) művének tekintette a Kádár-korszak a továbbiakban. Ez a konstrukció átszivárgott a „köztudatba” és túlélte még a rendszerváltást is. Ezeknek a társadalmi rétegeknek a részvétele nyilvánvalóan nem illett bele se a KB se az abortusz-ellenes lobbi koncepciójába. Valószínúleg se az egyik, se a másik nem rendelkezett értelmezési sémával, mindenesetre tartózkodtak ezeknek a rétegeknek az abortusz-kérdéshez való viszonyának elemzésétől.

Mint láttuk, Kornidesz Mihály szerint a beadványnak azért kellett politikai jelentőséget tulajdonítani, mert a petíció „,szerkesztői tudatos politikai ellenfeleink közül kerültek ki” és az abortusz-szabadság megszigorítását „politikai különvéleményük meghirdetésére és csatlakozók toborzására” használták ki, használták fel. ${ }^{25} \mathrm{Ez}$ az összeesküvés-felfogás a Rákosi- és Kádárrendszer közös vonása volt. Az előbbi az erőszak szélsőséges fokáig vitte el a „védekezési” módszereket, az utóbbi jelentősen enyhített rajtuk a 60-as évek elejétől az ,aki nincs ellenünk, az velünk van” doktrína meghirdetésével. Mint gondolkodási keret, mint az iránytűn az észak, meghatározta a politikai vezetők ítéleteit. Heller Ágnes szavaival (Interjú 2015): „két dolog volt: az egyik a fogalmazvány, a másik az ügy. Az ügy nem volt direkt politikai ügy, de indirekt [módon] politikai ügy volt. Mert minden megmozdulás, amit nem a párt vagy a szakszervezetek kezdeményeztek, önmagában véve államellenesnek számított.”

\section{A Belügyminisztérium értékelése: Szankciók a szervezők és aláírók ellen}

Az 1973. október 4-i elemzés csak a párttag aláírókkal foglalkozik. „Az értelmiségi aláírók (îrók, művészek, tudományos kutatók) között találhatók ismert párttagok is. Javasoljuk, hogy a kerületi, vagy hivatali és intézményi pártbizottságok beszélgessenek velük eljárásuk helytelen voltáról." ${ }^{26}$ A „beszélgetés” szó meglepően jóindulatú kezelést sugall. A pártból való kizárás

\footnotetext{
${ }^{24}$ MNL 288.f.36/1973/34.ö.e. 85. lap.

${ }^{25}$ MNL MSZMP-KB 288.f.36/1973/34.ö.e. 44. lap.

${ }^{26}$ MNL-MSZMP-KB 288.f.36/1973/34.ö.e. 45. lap.
} 
szükségességére nem utal; implicit javaslata, hogy a petíció aláírását vagy terjesztését meggondolatlanságnak, a párttagok egyszerű tévedésének tekintsék az MSZMP helyi szintjein. Ennek ellenére minimum egy párttagot, Bauer Tamást a Közgazdasági Tudományos Kutató Intézet munkatársát kizárták a pártból.

A már idézett december 12-vel datált, az MSZMP Budapesti Bizottsága Propaganda és Művelődési Osztályától származó, Kornidesznek küldött beszámolóból, mely a párttag aláírókkal folytatott beszélgetések első tapasztalatairól szól megtudjuk, hogy

A Közgazdasági Tudományos Kutató Intézet két fiatal párttagja, Bondár Éva és Bauer Tamás - akik az elmúlt hetekben nem pártfórumokon ismételten, részletesebben kifejtették a népesedési határozattal szembeni oppoziciós álláspontjukat - a figyelmeztetést is szó nélkül vették tudomásul. Velük szemben az újabb pártszerűtlen fellépéseik miatt az alapszervezet pártfegyelmit kezdeményez. Az ELTE-n Vidrányi Katalin, aki 'minden adminisztratív intézkedésben a személyes szabadság megsértését látja' a beszélgetés után még gondolkodási időt kért. ${ }^{27}$

A Közgazdasági Tudományos Kutató Intézet pártalapszervezetének 1973. november 29-i taggyüléséről készült jegyzőkönyvében olvashatunk Bauer „,párttaghoz méltatlan” magatartásáról:

Bauer Tamás a KISZ alapszervezetünk nevében az V. kerületi KISZ Bizottság küldöttértekezletén elmondta véleményét az $\mathrm{AB}$ rendeletről. Elővett egy magnót és hozzászólását felvette és fel akarta venni magnóra azt is, amit az ő hozzászólásához mások szólnak. Tulajdonképpen nyílt volt a kerületi KISZ bizottság előtt, hogy ez bizalmatlanság. ${ }^{28}$

2015-ben többen elmesélték, hogy hogyan zajlottak le a „beszélgetések”. Ma már a visszaemlékezőket is sokszor mosolygásra késztetik, letűnt idők abszurd anekdotáinak számítanak.

Bauer Tamás (Interjú 2015) olyannyira nem volt hajlandó megbánni, amit tett, hogy nem is egyszer, hanem kétszer zárták ki a pártból. A kizárás egyik oka, a rendőri nyomozás segítésének megtagadása volt: „[...] azért zártak ki a pártból, mert nem mondtam meg, hogy kitől kaptam [a petíciót], és kinek adtam vissza a végén”. A második kizárást az MSZMP különböző szintjeinek eltérő hozzáállása vagy a különböző szintek közötti kommunikáció elégtelensége magyarázza.

${ }^{27}$ MNL-MSZMP 288.f. 36/1973/34.ö.e.B/PMO/424.61. lap.

${ }^{28}$ BFL XXXV.10.c.1973/4.ö.e. 6-7. lap. 
A petíció miatt zártak ki, tehát amiatt, hogy pártunk politikája ellen folytattam ezt a dolgot [az aláirásgyújtést]. Akkor második lépésben a budapesti pártbizottságon visszavettek és enyhítették a büntetést a fellebbezésem hatására, szigorú megrovásra, de a Központi Ellenőrzési Bizottság, a KEB felülvizsgálta ezt, ott megint behívtak, és megint kizártak, úgyhogy kétszer zártak ki a pártból.

De állásából nem távolították el, amit, úgy gondolja, egy véletlennek köszönhetett:

Az a nagy szerencsém volt, hogy az intézetből nem dobtak ki, ami Nyers [Rezső] érdeme volt. Ô volt az igazgató akkor már, mert ugye '74-ben dobták őt ki a KB titkárságából és csináltak belőle Közgazdaságtudományi Intézet igazgatót, és amikor ez a másodfok volt, vagy harmadfok, akkor már ő volt az igazgató. Úgyhogy ilyen módon megtették nekem azt a szívességet, hogy kizártak a pártból, és emiatt soha később nem kellett magamnak föltenni azt a kérdést, hogy párttag legyek-e vagy sem.

A Soós Károly Attila, Közgazdasági Tudományos Kutató Intézet kutatója által a Kornidesznek írt december 12-i beszámolóban ${ }^{29}$ nem szereplő második aktív aláírásgyüjtő a Baueréhoz hasonló bonyolult procedúrákon ment át, míg végül sikerült elfogadtatni a KISZ-titkárságról való lemondását, de állásától, ugyancsak Nyers Rezsőnek köszönhetően, nem fosztották meg. ${ }^{30}$ A Kutató Intézet harmadik aktív aláírásgyűjtője, Bondár Éva „elég gyorsan elment” az intézetből. ${ }^{31}$ Bondár Éva „meggondolatlan” viselkedéséről az intézet pártalapszervezetének 1973. november 29-i taggyűléséről készült jegyzőkönyve számol be. Két vétket ró fel neki az alapszervezet:

Bondár Éva elvtársnő az Egészségügyi Szervezők Tudományos Egyesület által a népesedéspolitika aktuális kérdéseirôl szervezett ankéton jelent meg, ahol az volt a cél, hogy megértessék a jelenlevőkkel, miért vált szükségessé e rendelet. Orvosok, egészségügyi, munkaügyi szakértők a maguk módján, eszközeivel próbálták e rendelet jogosságát felvázolni. [...] Bondár Éva nem ismerve fel a helyzetet, elrontotta azt a célt, amit a Párt tűzött ki. [...] Még ennél is tovább ment Bondár elvtársnő: faliújságot szerkesztett, ami az $\mathrm{AB}$ [szigorítási] rendelet elleni agitáció folytatása volt. Felvázolta hány egyszobás, kétszobás, 3 és több szobás lakás van és hány lakásban nincs fürdőszobamosdófülke Budapesten, a városokban és községekben, hány lakásban nincs

${ }^{29}$ MNL MSZMP Központi Bizottsága Közoktatási, Kulturális és Tudományos Osztály 288.f. 36/1973/34. ö.e. B/PMO/424.61. lap.

30 Soós Károly Attila interjú 2015.

${ }^{31}$ Soós Károly Attila interjú 2015. 
WC, [...] nagy betűkkel! Nyilvánvaló volt az összefüggés az AB rendelet elleni tiltakozás és a faliújság között! 32

Nem párttag aláírók is kaptak büntetést, de ehhez valami külön ok kellett még. Klaniczay Gáborra például csak egy évvel később figyeltek fel, amikor barátjával, Pajkossy Gáborral tiltakoztak az ellenem, Körösi Zsuzsa ellen indított fegyelmi eljárás ellen (Interjú 2015). A bölcsészkar dékánjához beadott levelükben különösen azt a kitételt nehezményezte a dékán, amelyben az alkotmányra hivatkozva, legálisnak tekintették a petíciót és az aláirásgyűjtést. A büntetés az egyetem befejezése utánra „beigért” ún. tudományos továbbképzési ösztöndíj megvonása volt. „Különösen ezt az alkotmányra hivatkozást, ezt nagyon nehezményezte [Székely György, dékán, középkori történész, tanszékvezető]. Az érdekes egyébként, hogy az mennyire vörös posztó [volt], hogy hogy mernek itten ezek a taknyosok az alkotmányra hivatkozni."

Lángh Júliával (Interjú 2015), aki szintén nem volt párttag, munkahelyén, a Kossuth Rádióban nem elbeszélgetett a párttitkár, hanem közölte vele, hogy az aláírásgyüjtés miatt megszüntették a munkaviszonyát. Az ürömben az öröm az volt, hogy ezúttal, először, úgy érezhette Júlia, hogy nem férje (Konrád György) ügye, hanem saját tette miatt kapta a személyére kiszabott büntetést:

Telt-múlt az idő, nem olyan nagyon sok, és aztán egy szép nap [...] hivatott a pártitkár. A párttitkár engem?!? Nekem mi közöm a párthoz? Sejtettem, hogy ebből valami jó nem lesz, dehát na, hivatott, megyek. Azt mondja a párttitkár [...], hogy vegye tudomásul, hogy maga soha többet ebben a rádióban meg nem szólalhat és nem azért, mert a férje olyan, amilyen, pedig ő is megéri a pénzét, hanem azért, amit maga csinált és én ekkora dicséretet rég nem kaptam, tudod, milyen menő vagy, hogy végre saját jogon kapok ki, nem csak azért, mert a férjem felesége vagyok. [...] Én úgy tettem magam, hogy ugyan már, mit követtem el, mert azért arra az ember úgy már akkor is gőgösen vigyázott, hogy nehogy már azt higgyék ezek a hivatalosok, meg a rendőrök, meg az akárkik, hogy ők vannak felül, dehát ők voltak felül, mert ő tudott kirúgni. Szóval úgy tettem, mintha nem érteném, és akkor meg is magyarázta, hogy ezeknek a hölgyeknek [Károlyi Mihályné, Duczynszka Ilona, Rajk Júlia] az aláírását beszereztem, ennyi volt.

Lángh Júlia visszaemlékezései a beszélgetés részleteit illetően, ismét igazolják a gyanút, hogy készültek a BM III/III-as alosztályán jelentések az aláirásgyüjtés heteiben. Különben honnan tudta volna a párttitkár, hogy Júlia kikkel íratta alá a petíciót? Több aláíró, aláírásgyűjtő részvétele nem járt

32 BFL XXXV.10.c.1973/4.ö.e. 6-7. lap. 
következményekkel, vagy szinte alig; ók voltak Ránki Júlia szavaival (Interjú 2015) ,a díszzsebkendő a rendszer öltönyén [...], hogy... ne gyártsunk mártírt azonnal." Vagy ezért, vagy mert nem volt munkahelyük (Márkus Piroska, Betlen Anna, Dobos Éva, Karakán Melinda), vagy azért, mert elhagyták az országot (Szil Péter), vagy azért, mert munkahelyük a Párt intézményei között feszülő konfliktusok miatt valahogy védelmet jelentett számukra (Csákó Mihály), vagy azért, mert, mint Ránki Júlia (Interjú 2015) esetében, munkahelyükön múködött a dolgozók közötti szolidaritás, véletlenül akadt egy védangyal, aki olyan (nem feltétlenül hatalmi) pozícióban volt, hogy sikerült semlegesítenie a renitens személyek elleni vádakat és az ôket megillető büntetéseket.

Sólyom Andrást (Interjú 2015), akkor a Magyar Televízió segédoperatőrét enyhébb elbírálás illette. A Televízió múszaki igazgatója hívatta be magához, és fenyegette meg elbocsájtással, de csak akkor, ha a jövőben hasonló megmozdulásban részt vesz. Ahogy Ránki Júliával (Interjú 2015), a Magyar Televízió kezdő újságírójával, Sólyommal is a petíció aláirása és annak - viszonylag enyhe - következménye értette meg a joviális Kádárrendszer paternalizmusának korlátait, hogy a sok - megengedett, megtúrt fellépések mellett, valójában meddig lehetett elmenni a rendszer keretein belül.

Szász Domokos matematikus kutatóval (Interjú 2015) nem foglalkozott se munkahelyi párttitkár se más szerv. Sőt, meglepve tapasztalta három évvel később, 1976-ban, hogy amikor a KEOKH-ba behívták egy tudományos célú külföldi út kapcsán, és be akarták szervezni besúgónak, az abortusz-petícióban való aktív részvételét nem említették meg, mint zsarolási érvet. Hogy valójában nem tudtak-e róla vagy utasítást kaptak, hogy a petícióügyet nem kell tovább piszkálni, jobb, ha feledésbe merül, ezt nem tudjuk.

\section{A Belügyminisztérium értékelése: személyes történetem}

1974 tavaszáig lezajlottak a párttitkárok, igazgatók beszélgetései az aláirókkal, az elbocsájtások és az igazgatók többé-kevésbé „baráti” fenyegetései, majd az ügy elcsendesült nem csak pártvonalon, de az aláírók, aláírásgyűjtők tudatában is. Én voltam az utolsó a listán, az ELTE hallgatója akkor. Az ősz és tél folyamán velem nem beszélgetett el sem az ELTE, sem a bölcsészkar párttitkára, sem a dékán. De 1974. február 5-én a Belügyminisztérium III/III-4-b alosztálya úgy dönt, hogy tájékoztató jelentést küld „Kőrösi Zsuzsanna munkahelyére, az ELTE Bölcsészettudományi Karára. Ebben javasoljuk az egyetem állami és társadalmi vezetői felé, hogy ellene indítsanak fegyelmi vizsgálatot." "33

33 ÁBTL-III/III-4-b alosztály, Budapest, 1974 február 5. 
Azt, hogy hogyan éltem meg a fegyelmi eljárás közötti hónapokat 2014 szeptemberében egy interjúban elmeséltem a Klub Rádióban Mélykúti Ilonának. Röviden összefoglalva, a fegyelmi tárgyalás idejére meglehetôsen magamra maradtam. Néhány nappal az államvizsga dátuma előtt két jó barátom, a már elhunyt Csalogh Zsolt és Pór György kísért el a tárgyalásra, ôk vártak a folyosón. Egyikünket sem lepte meg, hogy a fegyelmi bizottság tagjai nem olvasták a petíció szövegét. A Belügyminisztérium nyilvánvalóan egyszerú formalitásnak tekintette a fegyelmi eljárást, a fegyelmi bizottság tagjait, az egyetem oktatóit nem tartotta érdemesnek arra, hogy elküldjék nekik a petíciót, amelynek alapján fegyelmi határozatot kellet hozniuk. Vajon ők maguk kérték-e?

Az ÁBTL őrzi az ellenem indított fegyelmi eljárással kapcsolatos iratokat, a besúgók jelentéseit a fegyelmi tárgyalás előtt, és a fegyelmi jegyzőkönyvét. ${ }^{34}$ Ezekből érdekes, számomra eddig ismeretlen részletek tárultak fel. Köztük besúgók jelentései arról, hogy hogyan reagáltak ismerőseim, barátaim a fegyelmi eljárás hírére. Együtt éreztek velem, és azon gondolkoztak, hogy mit kellene tennem, hogyan kellene viselkednem a fegyelmi tárgyaláson ahhoz, hogy a lehetô legenyhébb büntetést kapjam. A két (író és filozófus) barátom beszélgetéséről készített jelentés meghökkentő ma számomra, ugyanakkor adalék is arról, hogy a petíció-akció milyen, merésznek semmiképpen sem mondható, a kiállásnak semmilyen esélyt nem adó, a kollektív fellépés gondolatát tökéletesen mellőző kontextusban zajlott le. Az 1974. június 14-én datált jelentés azt állítja, hogy a két beszélgető három gondolatot fejt ki, amiből a két utolsót idézném:

Felhívták [Körösi Zsuzsa] figyelmét arra, hogy [...] 2. állítson társadalmi védôt, aki az ő gyerekes meggondolatlanságára hivatkozik; 3. ő maga a szervezésben való részvételét tagadja, de egyéb vitába ne bocsátkozzon, túrje el társadalmi védôje bíráló megjegyzéseit." A besúgó a továbbiakban néhány mondatot idéz egyikőjüktől: „Azt mondtam Zsuzsának [...], ha meg nem nyikkanna, volna valami esélye. Minden kérdésre egyetlen mondatot mondani: 'én aláírtam, nem tudok róla, hogy bármibe ütköznék' ... Le kell tagadni kapásból mindent.”35

A besúgói jelentés mindkét szereplője időközben elhunyt, így 2015ben sajnos nem tudtam már ôket megkérdezni errôl a több mint 40 évvel korábbi beszélgetésről.

Én egészen más stratégián gondolkoztam, ezt finomítottam néhány közeli barátommal. Nem akartam semmit tagadni. Büszke voltam arra, amit csináltunk, különösen a petíció 1553 aláírójára. A petíció legalista, „kandid”

34 ÁBTL-3.1.7-T-9481/3/141. lap.

35 ÁBTL-3.1.7-T-9481/3/131-133. lap. 
szellemében a fegyelmi szabályzat komolyan vételét akartam folytatni. Az egyetemi jogszabályok a fegyelmi eljárást a bírósági perek mintájára határozták meg. Az én esetemben a Belügyminisztérium volt a - láthatalan - „ügyész”, a fegyelmi bizottság elnöke a „bíró”, a „vádlottat” pedig a „társadalmi védő” (egyetemi oktató vagy diák) védhette. Feltételeztem, hogy a tárgyalás feladata volt kideríteni a „vádlott” kihágását, hogy milyen jogszabály(ok)ba ütközött tette, majd hogy ennek megfelelően milyen büntetést érdemel. Ehhez a fikcióhoz akartam magam tartani.

A fegyelmi tárgyalás azonban nem így zajlott le. A jegyzőkönyv meglehetôsen hủen tükrözi az tárgyaláson elhangzottakat:

K. ZS.: Nem ismerem a fegyelmi tárgyalás anyagát.

Elnök: Akkor hogyan fog felkészülni?

K. ZS.: Szeretnék kérni egy időpontot, amikor megismerkedhetnék ezzel az anyaggal, illetve társadalmi védőmmel megtekinthetnénk az eljárás iratait.

Elnök: Ezzel kapcsolatban azt tudom közölni, hogy egy aláirásgyúitési kampány megszervezéséról van szó, amely teljesen kimeríti a társadalmi rend elleni szervezkedést. [...] A Mûvelődésügyi Minisztérium utal, de nekem a dékán elvtárs adott felhatalmazást, hogy ezt a fegyelmi eljárást vezessem le. A dékán elvtárs pedig azt közölte velem, amit maga is tud és a bizottság is tud.

K. ZS.: Úgy érzem, hogy ennyi információ nem elegendő ahhoz, hogy a fegyelmi eljárást lebonyolítsák. Amennyiben gondolják, hogy elegendó, akkor ezt a részvételem nélkül is megtarthatják, mert én úgy érzem, hogy ebben az esetben nekem semmiféle szerepem nincs, ha itt utasításról van szó, de ebben az esetben viszont szeretném, ha ezt jegyzőkönyvbe vennék, hogy tulajdonképpen velem csak azt a tényt akarják közölni, hogy leérkezett a minisztériumból egy ilyen utasítás a dékán elvtárshoz, és a dékán elvtárs utasította Báti tanár urat [a három tagú fegyelmi bizottság elnöke], hogy folytassa le ennek a kijelentésnek alapján a fegyelmit, és én vegyem tudomásul. Ha ez a fegyelmi eljárás ilyen, akkor nekem nem kell megjelennem, írásban is tudomásul vehetem, de akkor kénytelen leszek fellebbezni a felsőbb egyetemi hatósághoz. [...]

Lengyel István: [...] így döntöttek bizonyos hatóságok, hogy ezek ilyen jellegű [értsd: titkos] íratok és ezt a bizottságnak nincs joga megkérdőjelezni, ezzel szemben a bizottság nem folytathat le bizonyítási eljárást, hogy bizonyos nyomozási hatóságok milyen iratokat hogyan kvalifikálnak. ${ }^{36}$

Végül az 1974. június 17-ére tervezett tárgyalásra nem került sor. A „társadalmi védőm” lemondott erről a kényes szerepről. Levélben közölte velem, hogy mivel a Szabad Európa Rádió hírt adott az ügyről és a fegyelmi eljárásról, ez utóbbi politikai üggyé vált, amelyben nem kíván részt venni. A

36 ÁBTL -3.1.7-T-9481/3/141. lap. 
döntést postán kaptam meg: a Magyar Népköztársaság népesedéspolitikája elleni tevékenységem miatt kizártak az ország összes egyeteméről örökre.

\section{A petíció utórezgései, az ügy lezárása}

Az elbeszélgetések, megdorgálások, állásokból való kirúgások hónapjai ezzel végleg lezárultak. A történet többé-kevésbé meg nem történtté vált. Van azonban még egy utórezgés. Dalos Györgynek (Interjú 2016) érdekes, számomra az interjúig ismeretlen emlékei vannak Fekete Gyula magatartásáról, állásfoglalásáról az Írószövetségben, ami hozzátartozik a petíció 1973. szeptember utáni történetéhez:

A legérdekesebb tapasztalatom az volt, hogy én megkaptam akkoriban, mint írószövetségi tag az Írószövetség választmányi üléseinek a jegyzókönyvét, ami bizalmas [...] volt, és ott olvastam Fekete Gyulának a hozzászólását, aki felháborodott azon, hogy eljárást indítanak a petíció szerkesztői ellen, és követeli, hogy ezt a petíciót tegyék közzé, mert erről az ügyről vitát kell folytatni. [...] Más esetekben is láttam ốt nagyon okosan viselkedni, tehát ô pontosan tudta, hogy neki érdeke az, hogy ez a petíció nyilvánosságra jusson, mert akkor ő is nekimehet a pártnak.

A szervezők közül egyedül Márkus Piroska (Interjú 2015) beszélt csalódásáról a petíció-akció elmaradt folytatásával kapcsolatban:

Az, hogy elmentem Magyarországról, annak nagyon sok oka volt, és nem volt közvetlen kapcsolata [a petícióval]. Aminek viszont volt kapcsolata a dologhoz, az az, hogy szinte semmi más nem történt, mint a petíció. Szóval amikor én benne voltam a petícióban, azt hittem, hogy ezután... majd valami mást csinálunk, meg még egy harmadik dolgot. Azt hittem, hogy benne vagyok egy csoportban.

Mikor én is megértettem, amit a gimnazista Márkus Piroska, hogy ennek a néhányak számára feminista, a többségnek inkább emberjogi, nő-, gyerek-, családvédelmi kalandnak nem lesz folytatása, úgy döntöttem, hogy elhagyom az országot, Franciaországba emigrálok. Akkor nem tudtam Klaniczay Gábor és Pajkossy Gábor 1974-es tiltakozásáról, Klaniczay csak jóval később, Párizsban beszélt nekem róla. Vajon, ha akkor tudok két diáktársam kiállásáról mellettem, ellensúlyozta volna-e csalódásomat, elkeseredésemet? Megváltoztatta volna-e döntésemet, hogy elhagyom az országot? Ezt ma már nem tudom megítélni. A Belügyminisztériummal való egy éves ide-oda levelezés után férjemmel, Pór Györggyel megkaptuk a kért kivándorló útlevelet, egy egyoldalas lepecsételt hivatalos nyomtatott ívet, 
amely a személyi adatokon kívül egy nagybetúkkel szedett mondatott tartalmazott, miszerint az országba való visszatérésre ez az útlevél nem jogosít fel. Ezzel a papírral 1975 júniusában a Dunán elhajózhattunk Bécsig, onnan német barátokkal kocsival Németországba mentünk, ahonnan néhány napos németországi tartózkodás után Franciaországba. Valéry Giscard d'Estaing, az akkori Köztársasági Elnök programja szerint Franciaország France terre d’asile (menekültek földje) volt. Az ország befogadott, hamarosan politikai menedékjogot, majd 1978-ban állampolgárságot adott. Nemcsak minket fogadott be, hanem Dél-Kelet Ázsia menekültjeit, az emlékezetes boat people (csónakos emberek) tízezreit is.

$\mathrm{Az}$ emigrációs útlevelet, amelynek jogi lehetőségét férjemmel mi „fedeztük fel”, elsőként mi kérvényeztük nem családegyesítési, hanem politikai indokkal. ${ }^{37} \mathrm{Nem}$ tudtuk, hogy ezzel a kérvénnyel ötletet adtunk az ország vezetőinek. Ezután több ellenzéki filozófusnak, szociológusnak, írónak és családjuknak, valamint Halász Péter színtársulatának „felajánlották” a kivándorló útlevelet. Heller Ágnes (Interjú 2015) 40 évvel később így emlékszik vissza 1975-re, a kivándorlások évére:

Ezt még nem mondtam el neked. Hogy ott voltam, amikor búcsúztattunk téged. Ez olyan furcsa év volt [...] a búcsúztatások éve volt. Először elbúcsúztattunk titeket, azután elbúcsúztattuk Konrádékat és Szelényiéket. Aztán elbúcsúztattuk Márkusékat, Vajdáékat, és mire mi mentünk, már senki sem volt, aki elbúcsúztatott volna bennünket.

Később Veres Júlia és Márkus Piroska is elhagyta az országot.

Miért nem lett folytatása az 1970-es években elképzelhetetlenül sikeres abortuszhoz való jogot védő petíció-akciónak? Azt gondolom, hogy valószínúleg azért, mert a Belügyminisztérium „összeesküvés-elméletével” ellentétben, nem volt egy előre elgondolt, kidolgozott program mögötte. Nem nyitott új politikai perspektívát. Igy paradox módon legyintsünk-rá feminista kalandnak, női ügynek könyvelődöt el. Az 1973-ban végrehajtott tisztogatási akciók az úgynevezett „Lukácsista” filozófusok ellen, a bírósági eljárás Haraszti Miklós ellen, a március 15-i tüntetők tömeges letartóztatása, és a petíció résztvevői elleni szankciók, majd a szervezők egy részének emigrálása több évre jegelte a kollektív megmozdulás(ok) vágyát, ambícióját.

Dalos György (Interjú 2016) nem így gondolja. Szerinte azért nem lett folytatása, mert nem egy feminista mozgalom része volt, hanem egy elszigetelt akció:

37 ÁBTL-3.1.7-T-9481/3/136-140. lap. 
Kihúnyt, de a furcsa az, hogy a dolognak nem volt folytatása. Tehát a tiltakozás egyszeri volt [...], miután te ugye '75-ben hagytad el az országot, Juli elment, Piri elment és kifújt ez az egész történet. Na, most ez azért volt, mert nem volt feminista egyébként, mert nem volt a dolognak olyanfajta alapvetése, amiért az egyszeri tiltakozáson túl adott volna valami programot. A másik ok az volt, hogy ez nem volt ellenzéki időszak. Tehát ha ez '77-ben van, akkor ebből feminizmus lett volna vagy nőcsoport, mondjuk így. Tehát akkor itt lett volna az ellenzéknek egy nőcsoportja, ahogy az NDK ellenzékének volt nőcsoportja például.

Betlen Anna (Interjú 2015) emlékei részben megegyeznek Daloséval:

Nem, az abortusz petícióról az én emlékeim szerint soha nem volt szó [később]. Biztos, akik megírták a történeti visszaemlékezéseket, azok a kutatók, akik azzal foglalkoztak, hogy mi a magyar nőmozgalom története, ők nyilván beleütköztek ebbe az eseménybe, de soha senki az én környezetemben nem hivatkozott arra, hogy volt ez a petíció. Még azért fontos ehhez tudni, hogy [...] 1998-ban megint, szó volt az abortusz szigorításáról a parlamentben, és akkor azért volt megint egy nőmozgalmi fellendülés, [...] és akkor szó volt errôl a petícióról is.

1979-ben a „kalandnak” mégis lett folytatása. Ekkor is egy petícióról volt szó, a cseh ellenállással való szolidaritás kifejezése, amelyet 250 értelmiségi írt alá („Magyarországi értemiségiek”1979). Ezzel a petícióval szokták a Kádár-korszak magyar demokratikus ellenzékének megszületését datálni - mintha az 1973-as abortusz szigorítás ellen indított petíció nem létezett volna. Pedig az aláirók jelentős része hat évvel korábban aláírta vagy pártfogolta az abortusz-petíciót, nevük ott szerepelt az 1553 aláíró között. A két petíció, 1973 és 1979 közötti kapcsolatra való explicit utalást azonban nem olvastam se akkor, se később. Interjú-kérdéseim között sem szerepelt az abortusz-petíció és az 1979-es és a későbbi demokratikus ellenzék közötti kontinuitás kérdése. Heller Ágnes (Interjú 2015), Bauer Tamás (Interjú 2015) és Szebeny Jenő (Interjú 2015) azonban beszélnek róla. Bauer Tamás (Interjú 2015) szerint az 1973-as akció úttörő szerepet játszott:

Annyi kapcsolatot látok, hogy ez [az abortusz-petíció] az első fontos alkalom volt, amikor egy ilyen politikai aktus megtörtént. És utána azt hiszem, hogy a Charta következett '79-ben. Úgyhogy [az abortusz-petíciónak] [...] úttörő szerepe volt, azt hiszem.

Szebeny Jenő szerint az [abortusz-petíció] „egy folyamat kezdetén volt” és ennyiben „dicsőséges helye van azáltal, hogy elindult egy olyan folyamat, hogy az emberek elkezdtek megnyilvánulni és még egy diktatúra viszonyai között is egyre többen felvállalták azt.” 
Ennek az írásnak az volt a célja, hogy egyfelől ne merüljön feledésbe a Kádár-rendszer és a magyar ellenzék történetének ez az 1973-as izgalmas epizódja. Másfelól egy ellen-narratíva megírása a Belügyminisztérium által konstruált, egy-két személy köré bagatellizált koncepcióval szemben, hogy az egykori résztvevők segítségével megértesse, a várakozásainkat felülmúlóan sikeres akció, az 1553 aláirás megnyerése éppen azért volt lehetséges, mert nem egy-két személy akciója, hanem a kollektív cselekvés múve volt. Ha lesznek hozzászólások, és elókerülnek újonnan talált dokumentumok, akkor két irányban látom folytathatónak az itt elkezdett munkát. Egyrészt a történet részleteit lehetne pontosítani, másrészt folytatni lehetne magát a történetet 1989. után, amikor az abortusz-petíció számos aláirója, aláírásgyújtője, támogatója fontos politikai szerephez jutott a megváltozott politikai rendszerben. Vajon hogyan érvényesítették a másfél évtizeddel korábbi eszményeiket?

\section{Felhasznált irodalom}

Acsády, Judith. 2016. „Megtettük-e azt, amit az eszményeink szerint meg kellett volna, hogy tegyünk? Az államszocializmus demokratikus ellenzékének elmaradt nőemancipáció-reflexióiról." Socio.bu. Társadalomtudományi Szemle 2. Letöltés: 2019. december 10.

Csizmadia, Ervin. 1994. A magyar demokratikus ellenzék (1968-1988). Dokumentumok. Budapest T-Twins.

Fekete, Gyula. 1972. Éljünk magunknak? Budapest: Szépirodalmi Kiadó.

Heller, Mária, Némedi Dénes \& Rényi Ágnes. 1990. „Népesedési viták Magyarországon 1960-1986." Adatbank. Erdélyi Magyar Elektronikus Könyvtár. Letöltés: 2019. december 10.

„Magyarországi értelmiségiek nyílt levele a Charta 77 aláíróihoz." 1979. Magyar Füretek. Letöltés: 2020. december 28.

Sasvári, Edit. 2000. Miért éppen Pór? A kádári „ïzenési” mechanižmus ermészetéhez, Budapest: Országos Széchenyi Könyvtár, 1956-os intézet és Oral History Archivum.

Puntigán, József. 2017. „Negyven éve jelent meg a Charta 77 első nyilatkozata.” Körkép.sk. Letöltés: 2020. december 28. 